\title{
Competing Collective Narratives in Intergroup Rapprochement: A Transgenerational Perspective
}

\author{
Margareta Jelić ${ }^{1}$, Dinka Čorkalo Biruški ${ }^{1}$, Dean Ajduković ${ }^{1}$ \\ [1] Department of Psychology, Faculty of Humanities and Social Sciences, University of Zagreb, Zagreb, Croatia.
}

Journal of Social and Political Psychology, 2021, Vol. 9(2), 370-400, https://doi.org/10.5964/jspp.6939

Received: 2017-09-05 • Accepted: 2021-02-02 • Published (VoR): 2021-09-01

Handling Editor: Guy Elcheroth, University of Lausanne, Lausanne, Switzerland

Corresponding Author: Margareta Jelić, Department of Psychology, Faculty of Humanities and Social Sciences, University of Zagreb, Ivana Lučića 3, 10000 Zagreb, Croatia. E-mail: mjelic@ffzg.hr

\begin{abstract}
In the context of an ethnically divided community, we explored the role of competing group narratives for intergroup rapprochement after violent conflict. In Study 1, data from a community survey conducted in Vukovar, Croatia, among 198 Croats, the local majority, and 119 Serbs, the local minority, were analysed to gain perspective on different narratives about the recent war and effects they may have on intergroup relations. In Study 2, focus groups with Croat and Serb children provided data to explore how these narratives were transmitted and transformed in living experience within the second generation. The quantitative results confirm the existence of opposing narratives of war among local Croats and Serbs. Multiple regression analyses show that, after controlling for exposure to war event and their personal impact, different factors predict rapprochement within the two groups. In the minority status group, that displayed higher overall levels of readiness for rapprochement, perceived ingroup victimization and outgroup stereotypes appeared more predictive than the outgroup affect. In contrast, within the majority group, variations in readiness for intergroup rapprochement were primarily predicted by outgroup affect, followed by perceived ingroup victimization. The qualitative inquiry complemented the findings from the survey. Despite the overwhelming dominant narrative, some alternative positions exist, but not consistent enough to be declared publicly. Perception of one's own group as the primary victim of the war influences not only interpretations of the past, but also shapes identity, everyday life and future expectations. Mechanisms of perpetuating opposed narratives, as well as possible interventions, are discussed.
\end{abstract}

\section{Keywords}

competing narratives, intergroup rapprochement, interethnic conflict, Vukovar, mixed method study

\section{Sažetak}

U kontekstu etnički podijeljene zajednice ispitali smo koju ulogu imaju suprotstavljeni narativi o nedavnoj prošlosti u približavanju dviju strana nakon međugrupnog sukoba. U prvoj studiji analizirali smo podatke prikupljene u na uzorku 198 Hrvata i 119 Srba u Vukovaru, kako bi se utvrdila uloga suprotstavljenih narativa o ratu u međugrupnim odnosima dvadesetak godina nakon sukoba. U drugoj studiji analizirali smo podatke dobivene u fokusnim grupama s djecom hrvatske i srpske nacionalnosti iz Vukovara, kako bi se istražilo kako se narativi o ratu prenose i kako oblikuju životno iskustvo mladih druge generacije. Kvantitativni podaci potvrđuju postojanje suprotstavljenih narativa o ratu kod vukovarskih Hrvata i Srba. Regresijske analize pokazuju da, nakon kontrole razine traumatizacije, različiti faktori predviđaju međugrupno približavanje kod dviju grupa. U manjinskoj grupi koja ujedno pokazuje veću spremnost za međugrupno približavanje, percipirana grupna viktimizacija i stereotipi o vanjskoj grupi pokazali su se boljim prediktorima od afekta. Nasuprot tome, kod većinske grupe varijacije u spremnosti na međugrupno približavanje se prvenstveno predviđaju emocijama prema vanjskoj grupi te percipiranom viktimizacijom vlastite grupe. Unutar većinske etničke grupe samo je vrlo mala skupina - među kojima su brojnije žene i oni koji su živjeli u Vukovaru tijekom rata - imala drugačiji narativ o ratu i smatrala da su obje skupine jednako patile tijekom rata. Kvalitativna analiza potvrdila je nalaze kvantitativnog istraživanja. Iako je 
dominantni kolektivni narativ sveprisutan, postoje neka drukčija stajališta, no nedovoljno konzistenta i jasna da bi se javno deklarirala. Percepcija vlastite grupe kao primarne žrtve u ratu utječe ne samo na interpretaciju prošlosti, nego oblikuje i identitet, svakodnevni život i očekivanja od budućnosti. U radu su raspravljeni faktori i razlozi održavanja suprotstavljenih narativa.

\section{Ključne riječi}

suprotstavljeni narativi, međugrupno približavanje, međugrupni sukob, Vukovar, miješana metoda

\section{Non-Technical Summary}

\section{Background}

How do people start to trust each other again and possibly reconcile after years of a severe intra-community conflict and massive violence? How do they make sense of what has happened in the community and how does the construction, transmission and preservation of a war narrative facilitate or hinder the peace-building process and community social recovery? In order to answer these questions we conducted a study in the post-conflict settings of the city of Vukovar, Croatia, where formerly belligerent group - majority Croats and minority Serbs - continue to live in the same community and try to rebuild their lives with the burden of the 1991-1995 war.

\section{Why was this study done?}

Collective narratives that groups in conflict construe about the causes, development, and the ending of their conflict may shape their future relations. When these narratives are congruent across conflicted groups, a prospect of future peaceful relations is possible; however, groups in conflict usually have profoundly different views about their disputes. These contesting narratives describe past grievances and violence that groups inflicted on each other very differently, honouring and remembering only ingroup suffering and injustice done to the in-group. Such one-sided narratives may be (mis)used in instigating and fuelling new intergroup conflicts. To foster post-conflict intergroup rapprochement it is important to understand the narratives that rival groups have about the conflict, the underlying intergroup emotions and cognitions, and the way they are reproduced and transmitted to the offspring.

\section{What did the researchers do and find?}

We conducted two studies. The first was a community sample survey of the Croat and Serb adults in the post-conflict city of Vukovar, Croatia, exploring different perspectives on the conflict and the relation of their respective narratives with intergroup rapprochement. To explore collective narrative, we used a range of logically connected variables, such as personal and collective war-related experiences, cognitive and emotional intergroup responses, and attributions of victimhood. We wanted to see if intergroup rapprochement can be predicted by variables tied to collective narratives. In the second study, we ran a series of focus groups discussions with Vukovar adolescents aged 11 through 15 to explore if and how these narratives have been transmitted and transformed in living experience within the second generation.

Results of Study 1 showed that different factors predicted variations in readiness to rapprochement within the two groups. Perceived in-group victimisation and stereotype of the outgroup as competent explained differences within the minority (Serb) group, rather than outgroup affects. Overall, this group seemed more ready to approach the outgroup than the Croat majority. The majority group's lower readiness for rapprochement might reflect their higher power status and lower need to accommodate. Variations within this group are best predicted by diffrences in affect towards the outgroup. Moreover, perceived collective victimhood strongly shaped Croats' ethnic identity and outgroup emotions. This pattern suggests that a dominant war-related narrative has formed, which associates Croat identity, a sense of victimhood and negative affects towards Serbs, alongside a minority-within-the-majority position, characterised by consistently low levels of endorsement across all of these factors.

The focus groups discussions of how adolescents perceived and interpreted their respective in-group narrative completed the findings from the survey. In the generation born and raised after the war, opposing narratives of the war persisted. In the majority (Croat) group, perception of one's own group as the primary victim of the war influenced not only interpretations of the past, but also shaped everyday life and future expectations. A one-sided perspective of the war was transmitted to children mostly within families and by the media, and often through silence about critical past events (justified by the need to avoid 
traumatisation), leaving little space for critical examination or debate. Thus, children had internalised ideologies, i.e. dominant narratives about the conflict, without access to clear facts about past events. Members of the minority group (that lost the war) appeared to typically react by self-silencing and avoiding the topic altogether.

\section{What do these findings mean?}

Contested narratives of the war and collective victimhood are important factors for intergroup rapprochement. Different factors, either more emotional (majority group) or more cognitive (minority group) may be responsible for different levels of readiness for rapprochement within the two groups. When transmitted to the next generation, the exclusive narrative of the war and in-group suffering may prevent the adolescents from critically examining history and contributing constructively to a more peaceful future. Therefore, we consider that dealing with diverse perspectives instead of silencing alternative narratives, may foster cross-group understanding and open promising ways to achieve lasting peace.

History isn't a single narrative, but thousands of alternative narratives. Whenever we choose to tell one, we are also choosing to silence others. Yuval Noah Harari, Israeli historian

As suggested by the citation above, historical understandings as reflected in collective narratives of intergroup conflict typically present partial perspectives. In particular, winners are more likely to publicly legitimize understandings focussing on the perspective of their own group. This is how one narrative prevails and alternative narratives are silenced, at least until the next conflict. Then they may resurface and further fuel a new round of intergroup conflict. In order to foster reconciliation and peace it is important to know what the narratives about a conflict are and to understand how conflicted groups explain their role in the conflict (Bar-Tal \& Salomon, 2006). Furthermore, it is even more important to explore whether alternative narratives exist, and if so, how they are negotiated and maintained in such circumstances and whether they are transmitted to the second generation. In this paper, we shall present two connected studies that focus on the question of opposed narratives on a recent conflict between Croats and Serbs in Croatia. In the first study we investigate their different narratives about the war and effects they may have on intergroup rapprochement. We shall use the term intergroup rapprochement when discussing the readiness of participants in this study for more positive intergroup relations in their daily life, as we believe it resonates with peoples' understanding of intergroup relations in a context such as Vukovar. This is also in line with the scholarly understanding that "reconciliation", while frequently used among scholars for many post-conflict contexts, may not be the most appropriate word in the case of divided societies, such as those presented in this paper. Instead of focusing on more demanding processes of reconciliation like apology and forgiveness, we explore more instrumental ways of how people try to cooperate and re-establish violated trust (Čorkalo Biruški \& Ajduković, 2016; Eastmond, 2010; Nadler, 2002). In the second study, we explore how these narratives have been transmitted and transformed in living experience within the second generation youth and how they feed into the relations with other groups. If the "others" are excluded from the category of victims in the dominant narrative of the past conflict, we are interested in the consequences of such denial (vs acknowledgement) of collective victimization for the second generation youth. Moreover, we specifically look for alternative narratives (supportive of peace making process) within each group and explore the potential they might have for building more positive intergroup relations.

The war in former Yugoslavia resulted in more than 140,000 deaths, great suffering and destruction of multi-ethnic ties and communities (Stockholm International Peace Research Institute, 1995-1996). Several places became symbols of national suffering. The city of Vukovar is among the places that became symbols of Croats' national suffering and destruction. Almost 25 years after the end of war it is an ethnically divided community, with two major ethnic groups living next to each other, but practicing very limited close contacts (Čorkalo Biruški, 2016; Čorkalo Biruški \& Ajduković, 2016; Reidy, Taylor, Merrilees, Ajduković, Čorkalo Biruški, \& Cummings, 2015). The city of about 27,700 is inhabited by two major ethnic groups: 57\% Croats and 35\% Serbs (Croatian Bureau of Statistics, 2011). The war that followed Croatia's declaration of independence in 1991 included a three-month siege of the city and Croat defenders' surrender to the Yugoslav Army and Serb paramilitaries. During the siege, the city was tremendously destroyed and over 1,500 
people were killed. After the fall of the city, the remaining non-Serb population ended up in prisoner-of-war camps in Serbia or was expelled from the city to the territories under control of the Croatian government. A major atrocity was the execution of over 250 Croat wounded soldiers and civilians at a nearby farm by the Serb paramilitaries and Yugoslav Army. The bodies were secretly buried in a mass grave, which became the most painful commemoration site of the Croatian Homeland War. Only a handful of perpetrators of this crime were prosecuted at the ICTY, and some of the local courts, over the following 25 years. The profound feelings of betrayal by the outgroup during the war lead to deteriorated intergroup relations between Croats and Serbs (Ajduković \& Čorkalo, 2004; Sekulić, Massey, \& Hodson, 2006). Individual and collective traumatization have been highlighted as obstacles to the capacity of Croats in Vukovar to trust Serbs and rebuild relations with neighbours who were on the other side of the conflict (Čorkalo Biruški, 2016; Čorkalo Biruški, Ajduković, \& Löw Stanić, 2014). Major obstacles for improving intergroup relations remain Croat's perception that their victimization is underacknowledged by the Serbs, on the one hand, and Serbs' sense of ethnic structural inequalities, on the other (Čorkalo Biruški \& Ajduković, 2009, 2012). Moreover, Serbs from Vukovar argue that Serb victims from Vukovar, although less numerous, remain un-acknowledged by Croats, which constitutes an additional obstacle for the restoration of social ties between both groups. Young people in the city grow up in a context of ethnic tension, and are separated in schools from their peers of the other ethnicity, which is the most evident example of ethnicization of everyday life (Čorkalo Biruški, 2012). These young people have no personal experience of a previously integrated community with harmonious intergroup relations and interethnic friendships (Ajduković \& Čorkalo Biruški, 2008). The political socialization of young people maintains the current state of relations through family, public and media narratives (Reidy et al., 2015).

These findings suggest that the two groups might have very different collective narratives of the causes and events that led to the war and their respective roles during the war. Their opposed narratives are reflected in different memories and interpretations related to the beginning of the war, its development and ending (Čorkalo Biruški \& Ajduković, 2009). An example is the commemoration of Operation Storm, a military operation by the Croat army in 1995 that brought all parts of Croatia under government control, but resulted in a mass exodus of ethnic Serbs. It is celebrated as a day of national liberation among Croats, but mourned among Serbs as a national tragedy (Clark, 2012; Čorkalo Biruški \& Ajduković, 2016). Such different perspectives and experiences prevent groups from forming shared beliefs about their common past (Bar-Tal, 2013) and often represent a serious obstacle in improving post-conflict intergroup relations (Cairns \& Roe, 2003).

In terms of an integrative approach to psychosocial barriers to conflict resolution, collective narratives can be understood as societal beliefs or social constructions that coherently interrelate a sequence of historical and current events, to reflect and constitute the collective's shared identity (Bar-Tal \& Salomon, 2006). They are a response to the basic human need to live in an organized, predictable and controllable world. Collective narratives influence both perception of the conflict and its management by justifying the outbreak of the conflict, presenting a positive image of one's group, delegitimizing the opponent, and presenting the ingroup as a sole victim of the conflict (Bar-Tal \& Salomon, 2006). Such a narrative usually provides a black and white picture of the conflict, where one side (opponent) is the aggressor and the other (ingroup) the victim. Many studies focused on the role such collective narratives play in the process of reconciliation (Bekerman \& Zembylas, 2012; Biton \& Salomon, 2006; Psaltis, Franc, Smeekes, Ioannou, \& Žeželj, 2017). According to Bar-Tal and Halperin (2011) such beliefs can become rigid and resistant to change if so-called "freezing factors" are present. These include structural, motivational, and emotional aspects, as well as threatening context, which all result in limited information processing and rigid conflict-supporting beliefs. A recent study conducted in Northern Ireland and Cyprus showed that, for both majority and minority groups, if group members feel threatened, they are more likely to endorse their ingroup's historical narrative, as this helps them to maintain a sense of continuity of their ingroup identity (Smeekes, McKeown, \& Psaltis, 2017). We believe that Vukovar fits into such a description of a threatening context, where perception of threat leads to more stereotypical judgments of the opponent and emotions "serve as glue that's holding the conflict supporting beliefs together" (Bar-Tal \& Halperin, 2011, p. 224). According to Halperin, Sharvit, and Gross (2011) emotions play a central role in conflict resolution. They suggest that, while anger, fear and hatred are crucial for escalation of conflict, positive emotions, such as empathy and friendship, are necessary for constructive coping with dominant narratives of the conflict and opening the way to intergroup rapprochement. 


\section{Structural Inequalities: The Case of Vukovar}

Several structural inequality factors indicate the disadvantaged position of the Serb minority, and some research findings reveal a very clear sense of being discriminated against among the Serb minority (Čorkalo Biruški \& Ajduković, 2009). While more systematic research on these issues is still lacking, controversial positions regarding these factors are well documented in the media. One example is the under-employment of minorities, including Serbs, in the local public services. The Constitutional Act on the Rights of National Minorities stipulates affirmative action regarding employment of ethnic minority members in the public sector, proportionally to their number in the local population. The Serb media report that, in the Vukovarsko-srijemska county, Serb's employment at such jobs is about five times less than legally required. The rate of employment of Serbs is better within the administration of Vukovar (25\%), but still lower than the 35\% of Serb participation in the local population (Manojlović, 2018). The justification by the Croat majority is that such provisions favour the Serbs too much, which is embedded in openly attributing collective blame to the outgroup for atrocities in the past conflict.

The second structural factor which is reflected in the Serb narrative is the failure of the state to prosecute the culprits for murders and disappearances of prominent local Serbs, several months prior to the outburst of violent conflict in August 1991. Interestingly, the political campaign and the protest led by the mayor of Vukovar in October 2018, targeted the judiciary for failing to bring to justice those culpable of crimes against the Croats during the war (Bajruši, 2018; HINA, 2018; Penić, 2018). The Serb community insisted that crimes against Serbs before the outbreak of the war should also have been included in this criticism. Some people view their absence in local officials' protest as a consistent policy of Croats' "selective approach to the victims" (Patković, 2018; Rašović \& Boban Valečić, 2018)

Furthermore, many people in the Serb community claim that the abolition for armed insurrection (Croatia: Law of 1996 on General Amnesty), which does not give impunity for war crimes, is malevolently interpreted by local Croat leaders at the expense of Serbs. Indeed, local Croat political leaders often object that the Serbs who were part of the Serb military when the Croats defenders of the city surrendered now work in public administration, police and judiciary, which they deem unacceptable (Bajruši, 2018; Orešić, 2018). Such positions maintain insecurity among the Serbs and when they are widely promoted by the media, tend to be perceived as instigating anti-Serb sentiments. They contribute to circulating the dominant narrative that not enough outgroup members (perpetrators) were prosecuted. In the public discourse of the majority's political leadership, the number of still missing victims is often emphasized, but these do not include missing Serbs from Vukovar.

Other policy issues are tied to symbolic intergroup threat. An example is the attempt of the central government in 2013 to implement the legal requirement (based on The Constitutional Act on The Rights of National Minorities) to put up bilingual signs and, in this case, in Cyrillic script in the public spaces. This is a routine practice in other municipalities where more than a third of the population belongs to an ethnic minority group. But in Vukovar, the response was orchestrated protests and demolition of "Serbian signs" by the crowds. The Croat protesters insisted that the "wounds were too fresh" for them to face "Serbian alphabet" in public spaces, which would add to the burden of having to face the Serbs in the streets who back then served in the enemy military (van de Ven, 2015). The attention was mostly focused on the appraisal of heroic deeds and victimisation of Croats (Žanić, Kufrin, \& Živić, 2016) which served to boost group identity self-assurance. The protests made the central government retreat and the signs are still not displayed.

An important area of perceived inequality are commemorations of civilian victims of war. Some Serbs consider that they are denied the right to remembrance and that Croats are not ready to acknowledge their victims - not even civilians, let alone their in-groups who fought the war on the other side (Banjeglav, 2012/2013). Even modest and very symbolic gestures of paying tribute to the Serb victims (e. g. throwing a wreath in the Danube river for the "innocent victims of Vukovar") were boycotted by the Croatian political representatives and the public (Raknić, 2018). Moreover, a majority of Croats, especially victims and war veterans, see statues and tombstones dedicated to Serb militia members as insulting tribute to the aggressors responsible for the killing of Croat neighbours, whereas Serbs invoke their customary right to commemorate the fighters who, in their words, defended their villages (Sabljak Gojani, 2011). If these memorials did not emphasize that these men died as "commanders in defence of their village", the memorabilia would probably be less provocative to the Croats. The reminders of victimised Croats are present in the public spaces throughout the town, 
since many streets bear the names of Croat military leaders and civilian victims. It is indicative that Croat school classes come each year to the memorial cemetery where hundreds of Croat victims are buried, but not the Serb classes (van de Ven, 2015).

Education is a highly controversial area. The Serb representatives criticise the county government for not allowing the municipalities with a Serb majority to register their own schools that teach children in Serbian language and cyrillic script (Mikić \& Božić, 2014). This right is guaranteed by the law and meant to ensure rights of minorities to maintain their culture and language. It is respected in communities where other ethnic minorities meet the legal requirements, such as the $1 / 3$ proportion of population in a given municipality. While Serbs frequently denounce a strong case of structural inequality, Croat officials avoid resolving the issue by shifting responsibility for it to different administrative levels, while ostensibly insisting that separate schooling leads to promoting ethnic division of children from the preschool age onwards (Čorkalo Biruški \& Ajduković, 2012).

\section{Theoretical Background}

Collective violence of the past continues to affect groups and individuals both through ongoing consequences in the present and through collective memories of historical victimization that shape present-day group narratives. In this paper our aim is twofold - to determine psychosocial factors that underlie competing narratives about the war and the effects they may have on intergroup rapprochement, and to explore if and how these collective memories of victimization are passed on across generations and how they are addressed, and feed into relations with other groups, within the next generation.

In order to foster intergroup rapprochement after an intergroup conflict it is important to understand the narratives of rival groups regarding the conflict and their role in it, intergroup cognitions arising from these narratives, as well as the underlying intergroup emotions. Competing narratives can be reflected in a series of cognitive and emotional responses shaping memories of the conflict and its role in constructing and maintaining group identity. In Study 1 we focus on three specific aspects of opposed narratives that can impact on intergroup rapprochement - competitive victimhood, outgroup stereotypes, and intergroup emotions. These three factors result from different perspectives among conflicted groups. By combining them, we want to offer a more integrated view on the role of competing narratives in conflicted groups and determine whether some are more relevant than others in predicting readiness to intergroup rapprochement. We procede by explaining the role of each of those factors in shaping two distinct war-related narratives.

First, there are different and competing narratives about war victimisation, i.e. competitive victimhood. Competitive victimhood is a tendency to see one's group as having suffered more than outgroups (Noor, Shnabel, Halabi, \& Nadler, 2012). However, not only war victimization counts. Often after the conflict ends, strong structural inequalities persist. Thus, perceptions of post-war injustices related to the group's minority or majority position, and discrimination experiences due to group membership, may also become a part of the group's victimhood narrative.

Second, according to the Stereotype Content Model (SCM; Fiske, Cuddy, Glick, \& Xu, 2002), competing narratives can be reflected in specific outgroup stereotypes, depending on the status of conflicted groups. Based on the described societal relations of the two groups in Vukovar, such power/structural inequalities combined with lasting conflict over scarce resources (evident through higher unemployment rates, lower socioeconomic status, etc.) could lead to lower readiness to intergroup rapprochement. However, we argue that the mechanism of transforming structural relations into behavioural intent might be different for the two groups. Specifically, the SCM maintains that all groups are perceived based on two distinct dimensions - competence and warmth - that relate to targets' perceived status and competition within society. The model posits that group stereotypes follow from social structure, with perceived status predicting competence stereotypes (outgroups are perceived as more competent to the extent that they are perceived as powerful and of high status) and perceived competitiveness predicting (lack of) warmth stereotypes. Thus, out-group prejudice often focuses on dislike or disrespect, but not necessarily on both. According to the SCM, status and competition together create four different types of outgroup stereotypes: 1) An outgroup stereotype of low warmth but high competence suggests envy and is a typical way of how lower status groups perceive groups of higher status. High-status 
out-groups may elicit certain respect or even admiration, alongside intense dislike motivated by a sense of threat. Such envious stereotypes should evoke feelings of threat, defensiveness, and resentment, and often result in violence (Glick \& Fiske, 2001). 2) An outgroup stereotype of high warmth but low competence suggests a paternalistic attitude towards the "nice but incompetent" group, usually reserved for the less successful groups in the society. 3) The combination of low warmth and low competence suggests contempt, which is typical for higher status groups' perception of the groups of lower status in a society. According to the SCM, these groups are rejected for their negative intent toward the rest of society (often viewed as parasitic and exploitative) and for their apparent inability to succeed on their own. 4) High competence and high warmth is usually reserved for the ingroup and/or its allies. Contemptuous and envious stereotypes of the outgroup could be seen as manifestations of opposed narratives indicating competition between groups and inequality of group status. Hence, in our study we expected members of disadvantaged groups (Serbs as the minority group) to be more likely to exhibit envious outgroup attitudes, whereas members of high-status groups (Croats, as the majority group) to be more prone to contemptuous outgroup attitudes.

Finally, narratives can be reflected in intergroup emotions. According to the Intergroup Emotions Theory (IET; Mackie, Smith, \& Ray, 2008), self-categorization determines emotional responses, especially for highly identified group members. Specific emotions engendered by belonging to a social group, once evoked, regulate intergroup behaviour and can become over time a part of group identity. Current intergroup emotional responses among Croats and Serbs in Vukovar may reflect their different conflict and post-conflict experiences and related narratives. Moreover, it can also regulate the maintenance of these narratives by either inhibiting or facilitating changes in the relations between the former adversaries. Both envious and contemptuous outgroup stereotypes result in negative emotions toward the outgroup (envy vs. contempt). However, whereas envy suggests that one groups cherishes something that the other group possesses and is focused on achieving the same (hence oriented towards that outgroup), contempt leaves no space for working on intergroup relations, as there is no motive or interest to do so. As IET posits that intergroup emotions guide intergroup action, this should result in more readiness among Serbs for intergroup rapprochement. This is consistent with studies showing that the lack of positive emotions, such as empathy or trust, can be detrimental for intergroup relations (Čorkalo Biruški, 2016; Jelić, Čorkalo Biruški, \& Ajduković, 2013; Nadler \& Liviatan, 2004; Vezzali, Capozza, Stathi, \& Giovannini, 2012).

Collective memory is never a mere reflection of the past, as present problems determine what is considered worth remembering and what can or should be forgotten (Kratochwil, 2006). Thus, collective memory is a mediated reflection of the past, which is closely linked to present needs and future aspirations (Haukanes \& Trnka, 2013). For survivors, remembrance (i. e. narratives of past victimization) is often part of the efforts towards achieving justice (e.g. McGrattan \& Hopkins, 2017) and the memory created by one generation is, through commemorative practices, passed to the post-war generation. Monuments erected by governments and official commemorations hold a special place in memory politics, as they interpret the past and attempt to form future public opinion (Smith, 2019). The post-war generation is thus expected to participate in those commemorations in order to learn the lessons of the past and project them onto their future. However, research shows the post-war generations often feel overloaded by war memories, especially when they overshadow more contemporary problems, like unemployment, or mass depopulation (Močnik, 2019).

In divided societies, such as the city of Vukovar, rival memories of the past conflict are often used as an ongoing arena of disputes between former adversaries pushing their distinct versions of memory (Baillie, 2019; Baliqi, 2018; Bilali \& Vollhardt, 2019; McDowell \& Braniff, 2014). This puts additional challenge on parents and teachers to find ways to talk about the past and negotiate "individual" narratives and competing collective memories (Bekerman \& Zembylas, 2017).

Intergenerational family memory research shows that families have a tendency to depict their ancestors as heroes and that the type of stories remembered is determined by family values (Švařičková Slabáková, 2019). Being a member of a group that either won or lost the war, makes a difference in the amount of acknowledgement one's narrative of the past will receive and, hence, how prone one is to share it publicly. The social environment conditions the discourses on pasts available to young people, and their group status, may play an important role. While for the majority group internalization of the dominant and institutionalized narrative is usually closely connected to their mnemonic socialization within families, for the minority group family memory can represent an alternative to the institutionalized past (Popov \& Deak, 2015). Specifically, majority group members can share their family stories in a prototypical fashion, 
depicting their ancestors as heroes, and fuelling nationalistic sentiments. By contrast, minority group members may strongly oppose the dominant narrative of the war, and either share alternative narratives of the past or choose to remain silent about these events. If their narrative is not transmitted overtly, it obscures understandings of the past for the next generation. A related problem lies in fact that narratives that are not shared cannot be contested neither, making it even more difficult for the minority adolescents to position themselves.

\section{Study 1 - Competing Narratives in Adults}

The first study explored different perspectives among both groups in the post-conflict setting, and the relation of competing narratives with intergroup rapprochement. Collective narratives about the war were investigated through a series of logically connected variables, such as personal and collective war-related experiences, cognitive and emotional intergroup responses, and attributions of victimhood.

\section{Method}

\section{Procedure}

In order to tap different narratives about the war and effects they may have on intergroup rapprochement, we analysed quantitative data from a community survey conducted in 2008. These data were collected 13 years after the end of the war in Croatia, and 17 years after the Vukovar massacre, on a community sample of 198 adult Croats and 119 adult Serbs living in Vukovar at the time of the survey. Participants were selected by a random-walk sampling technique and interviewed face-to-face, in an individual session at their homes. Interviews were all carried out by senior psychology students, and lasted about 45 minutes. In case the participants experienced discomfort or were upset by the procedure, professional psychological support in the community was assured. However, no participant asked for post-interview psychological care. The study was approved by the Institutional Review Board of the Department of psychology, University of Zagreb.

\section{Participants}

Participants from the two ethnic groups did not differ significantly by their sociodemographic characteristics (age, gender, education level, housing status, employment rate). Age of the participants ranged from 18-70, with an average age of 50.6 years. About $64 \%$ were females, reflecting the fact that more women than men lived in the city at the time of the study. About $23 \%$ of the participants completed only primary school, $63 \%$ had high school and about $14 \%$ had a higher education degree. Only $26 \%$ of participants were employed, $20 \%$ were unemployed, $50 \%$ were retired and $4 \%$ were students. This is consistent with the unemployment rate in Vukovar at the time of the study (Croatian Bureau of Statistics, 2009) and reflects the high level of retired Croatian veterans in the community, and the fact that the older population continued to live in the city.

\section{Materials}

The survey questionnaire included measures of ethnic identification, two measures of individual traumatization during the war (exposure to war events and impact of these events on the individual), two measures of collective victimization (ingroup perceived as innocent victim and competitive victimhood), perceived post-war victimization, outgroup stereotype, positive outgroup affects, intergroup rapprochement, perceived preconditions for reconciliation, and socio-demographic data.

Ethnic identification was measured with four items, with a 5-point Likert-type response scale (Doosje, Ellemers, \& Spears, 1995). The score is formed as a mean of all items, ranging from 1 to 5 , with a higher score indicating stronger ethnic identification (e.g.: I see myself as a Croat/Serb). Cronbach's alpha is .80 .

Individual traumatization. The operationalisation of traumatization level was two-fold. First, we focused on the measure of an individual's war experience, asking respondents to indicate whether they had experienced specific 
stressful or traumatic events during the war. Respondents were offered a list of 12 stressful and 14 traumatic events they might have experienced during the war based on previous studies (Čorkalo Biruški \& Ajduković, 2009). Examples of stressful events are: loss of a job, being hungry, sharing living space with strangers. Examples of traumatic events are: being wounded, witnessing a rape, death of a friend or family member. The score on each subscale corresponds to the sum of different (stressful or traumatic) events that the respondent experienced during the war. Second, we focussed on the impact of the experienced war events on the respondent, measured by the Impact of Event Scale (IES-R; Weiss \& Marmar, 1996; see more about results on the same sample in Čorkalo Biruški, Ajduković, \& Löw Stanić, 2014). Respondents assessed on a 5-point scale ranging from 1 (not at all) to 5 (extremely) how much they were distressed or bothered during the past seven days in relation to the indicated stressful or traumatic event during the war. A sample item is Any reminders brought back feelings about it. The score is formed as a mean of all items and the Cronbach's alpha in this study is 96.

Perceived collective victimisation was assessed by two measures. First, the perception of the ingroup as innocent victim during the war measured via a single item to which participants responded on a 5-point scale, with higher scores indicating stronger endorsement: My group was a victim in the war and therefore we cannot be responsible for the atrocities that were committed ${ }^{1}$. Second, competitive victimhood was measured by asking which group (Croats or Serbs) was the greater victim in the war. Participants answered by choosing one of the three options: 1 - Serbs were greater victims, 2 - Both groups were equal victims, or 3 - Croats were greater victims. Conceptually, 1 or 3 refer to high levels of competitive/exclusive victimhood, depending on who is being asked, while 2 refers to inclusive victimhood.

Perceived post-war victimization was assessed in order to compensate for the fact that data collection took place 13 years after the end of the war. Some international organizations reported on discriminations against Serbs regarding citizenship, employment, housing and experiencing hostility from the Croatian population and authorities (Immigration and Refugee Board of Canada, 2006). Thus, participants were asked to indicate whether or not they experienced discrimination (unequal treatment) after the war in each of the following areas: schooling, healthcare, employment, housing, judiciary, or the police procedures. The score represents the number of times an individual endorsed yes and could range from 0 to 6 . Higher scores thus indicate a wider range of different experiences of discrimination after the war.

Outgroup stereotype as a cognitive component of the relation toward the outgroup, was measured by a scale constructed for the purpose of this study. Respondents rated Croats and Serbs on 11 bipolar scales (e.g. selfish-unselfish, lazy-diligent, fair-unfair, honest-treacherous) with a response range from 1 to 5 . Higher score indicates a more positive stereotype towards members of the group in question. Drawing from the Stereotype Content Model (Fiske et al., 2002) that posits two distinct dimensions - competence and warmth, we conducted exploratory factor analysis separately for Croats and Serbs. Results confirmed the two-factor solution, after two bipolar scales being saturated with both factors were dismissed from further analyses. We named one factor Competence (e.g. lazy-diligent, stupid-smart, courageous-coward) and the other Warmth (e.g. insolent-kind, selfish-unselfish, hospitable-inhospitable). The internal reliability was satisfactory with Cronbach's alpha of .70 (Croats) and .78 (Serbs) for Warmth, and of .77 (Croats) and .83 (Serbs) for Competence.

Positive outgroup affect measures the emotional component of the relation toward the outgroup. The participants rated how much they feel a set of emotions towards the outgroup (friendship, respect, closeness, conciliation) on a 5-point scale. Specific emotions were chosen based on a pilot survey for the current study. Cronbach's alpha for this scale is .90 .

For the purpose of this study we constructed a measure of intergroup rapprochement. This 7-item scale assesses readiness to trust and cooperate with the outgroup members. Respondents were asked to indicate how much they agree with each statement on a five-point scale. A sample item is I believe that working on accomplishing joint goals is the best way to restore trust between Croats and Serbs. After reverse-coding 6 items, the score is formed as a mean of all items and the Cronbach's alpha in this study is .73 and .77 for Croat and Serb samples respectively.

1) We acknowledge that this item, besides including a sense of in-group victimisation, also includes the aspect of denial of in-group accountability. However, this denial reflects a belief in strong, if not even exclusive in-group victimisation (i. e. because of our victimhood status, we cannot be accountable for perpetration by our ingroup members). This is why we believe that the item describes first and foremost a belief in one's own group victimisation. 
Finally, in order to gain better understanding of their narratives, we asked participants what they consider to be the necessary conditions for reconciliation between Croats and Serbs. They could choose among 5 options: 1 - reconciliation should not take place, 2 - reconciliation is possible if all the wrongdoings committed by the outgroup are punished, 3 intergroup relations are going to normalize by themselves in time, 4 - each side needs to point to culprits for the war, 5 - we (Croats/Serbs) should make the first move towards reconciliation.

Demographic data included gender, age, ethnicity, education level, employment status and whether or not they lived in Vukovar during the war.

\section{Results and Discussion}

Differences between Croats and Serbs in all variables indicate different perspectives of the past and current events and situation in Vukovar at the time of the study (Table 1).

Table 1

Means, Standard Deviations, t-Test and Effect Sizes (Cohen's d) for All Variables (Study 1)

\begin{tabular}{|c|c|c|c|c|c|c|}
\hline Variable & Group & $N$ & $M$ & $S D$ & $t$ & Cohen's $d$ \\
\hline \multirow{2}{*}{$\begin{array}{l}\text { Ethnic identification } \\
(1-5)\end{array}$} & Serbs & 119 & 3.91 & 0.90 & \multirow{2}{*}{$-7.40^{\star *}$} & \multirow{2}{*}{0.83} \\
\hline & Croats & 198 & 4.57 & 0.67 & & \\
\hline \multirow{2}{*}{$\begin{array}{l}\text { Number of traumatic war events } \\
(0-14)\end{array}$} & Serbs & 117 & 3.59 & 1.93 & \multirow{2}{*}{$-7.54^{* *}$} & \multirow{2}{*}{0.91} \\
\hline & Croats & 193 & 5.70 & 2.63 & & \\
\hline \multirow{2}{*}{$\begin{array}{l}\text { Number of stressful war events } \\
(0-12)\end{array}$} & Serbs & 117 & 6.72 & 2.64 & \multirow{2}{*}{$-2.85^{* *}$} & \multirow{2}{*}{0.34} \\
\hline & Croats & 193 & 7.60 & 2.61 & & \\
\hline \multirow{2}{*}{$\begin{array}{l}\text { Subjective traumatization } \\
(1-5)\end{array}$} & Serbs & 119 & 2.07 & 1.06 & \multirow{2}{*}{$-4.06^{* *}$} & \multirow{2}{*}{0.48} \\
\hline & Croats & 194 & 2.60 & 1.16 & & \\
\hline \multirow{2}{*}{$\begin{array}{l}\text { Perception of ingroup victimization } \\
(1-5)\end{array}$} & Serbs & 114 & 2.95 & 1.32 & \multirow{2}{*}{$-7.01^{\star *}$} & \multirow{2}{*}{0.83} \\
\hline & Croats & 197 & 4.02 & 1.27 & & \\
\hline \multirow{2}{*}{$\begin{array}{l}\text { Post-war victimization } \\
(0-6)\end{array}$} & Serbs & 119 & 1.12 & 1.11 & \multirow{2}{*}{$3.61^{* *}$} & \multirow{2}{*}{0.42} \\
\hline & Croats & 198 & 0.64 & 1.16 & & \\
\hline \multirow{2}{*}{$\begin{array}{l}\text { Outgroup competence stereotype } \\
(1-5)\end{array}$} & Serbs & 118 & 4.01 & 0.69 & \multirow{2}{*}{$13.79^{* *}$} & \multirow{2}{*}{1.62} \\
\hline & Croats & 197 & 2.83 & 0.77 & & \\
\hline \multirow{2}{*}{$\begin{array}{l}\text { Outgroup warmth stereotype } \\
(1-5)\end{array}$} & Serbs & 118 & 3.30 & 0.88 & \multirow{2}{*}{$4.53^{\star *}$} & \multirow{2}{*}{0.52} \\
\hline & Croats & 197 & 2.84 & 0.89 & & \\
\hline \multirow{2}{*}{$\begin{array}{l}\text { Positive outgroup affect } \\
(1-5)\end{array}$} & Serbs & 119 & 4.19 & 0.74 & \multirow{2}{*}{$12.85^{* *}$} & \multirow{2}{*}{1.56} \\
\hline & Croats & 198 & 2.70 & 1.13 & & \\
\hline \multirow{2}{*}{$\begin{array}{l}\text { Intergroup rapprochement } \\
(1-5)\end{array}$} & Serbs & 119 & 3.85 & 0.84 & \multirow{2}{*}{$9.63^{* *}$} & \multirow[b]{2}{*}{1.08} \\
\hline & Croats & 198 & 2.93 & 0.86 & & \\
\hline
\end{tabular}

${ }^{* *} p<.001$.

As expected in the aftermath of interethnic conflict, the average ethnic identification level is high in both groups, but even higher among Croats, the majority group of higher status $(t=7.397, p<.001)$. It seems that among Croats, high ingroup identification is almost a norm. As shown before for a national sample (Čorkalo Biruški \& Penić, 2014), Croats on average experienced more war-related stressful events than Serbs, among those who still lived in Vukovar after the war. In Vukovar, the difference is even higher for traumatic war events, with Croats experiencing on average 6 and Serbs experienced 4 out of 8 possible traumatic events (Cohen's $d$ of 0.91 suggests this is a large effect). In line with that, the impact of the most painful war experience on our respondents today was also significantly stronger for Croats than Serbs, indicating that Croats on average felt more distressed by the experienced war trauma. Neither group feels especially responsible for atrocities committed during the war by the respective ingroup. While Serbs on average neither 
agree nor disagree with the statement that their group was a victim in the war and therefore cannot be held responsible for the committed atrocities $(M=2.95)$, Croats tend to agree with it $(M=4.02 ; t=7.007, p<.001)$. When the post-war period is taken into account, perception of victimization becomes even more fuzzy because Serbs consider themselves to be more discriminated against than Croats $(t=3.614, p<.001)$. However, it is noteworthy that, overall, the perceived discrimination level is low and mostly in employment.

Results show that Serbs consider Croats more competent and warm than vice versa: Serbs describe Croats as very competent, whereas Croats consider Serbs as below midpoint of the scale on both competence and warmth. In terms of the Stereotype Content Model (Fiske et al., 2002) Serbs' stereotype about Croats suggests envy, while Croats' stereotype about Serbs suggests contempt. This is a typical post-conflict pattern indicating that the two groups are in competition for resources with Croats having higher and Serbs lower status in Croatia. This is in line with findings showing that perceived power strongly predicted perceived competence in Central and Eastern European stereotypes (Phalet \& Poppe, 1997; Poppe \& Linssen, 1999). Recent studies also documented that people looking up the status hierarchy, display envy and Schadenfreude (Cikara \& Fiske, 2012) and people looking down the status hierarchy express contempt (Harris \& Fiske, 2006). Altogether, competence differentiated Croats and Serbs from Vukovar more than warmth (although the warmth effect sizes are also large by Cohen's (1992) standards, as can be seen from Table 1).

In the same vein, the data show a lack of positive affect towards the outgroup among Croats and moderately positive affect toward the outgroup among Serbs $\left(M_{\text {Croats }}=2.70, M_{\text {Serbs }}=4.19 ; t=12.854, p<.001\right)$. It is interesting to note that perceived innocent ingroup victimisation appears more consensual among Croats but controversial among Serbs, whereas the opposite stands for positive outgroup affect as well as the outgroup competence stereotype - which appear consensual among Serbs but displays genuine variation among Croats.

While most Croats in this sample consider their group a greater victim in the war, many Serbs consider both groups as equally victimized during the war (Table 2).

\section{Table 2}

Number of Serbs and Croats Who Endorsed Each Narrative of the Victimhood

\begin{tabular}{lcc}
\hline Narrative & Serbs & Croats \\
\hline Serbs were greater victims & 5 & 1 \\
Both groups were equal victims & 108 & 37 \\
Croats were greater victims & 5 & 160 \\
\hline
\end{tabular}

The two groups also pose different conditions for reconciliation (Table 3). For both groups punishing war crimes seems to be the key precondition for reconciliation.

Table 3

Percentage of Serbs and Croats Who Endorsed Each of the Preconditions for Reconciliation Between Croats and Serbs

\begin{tabular}{lcc}
\hline Precondition & Serbs & Croats \\
\hline Reconciliation should not take place & 0.0 & 7.1 \\
All wrongdoings committed by the outgroup should be punished & 6.8 & 51.3 \\
Spontaneous normalization & 26.3 & 17.2 \\
Each side points to culprits within ingroup & 62.7 & 23.9 \\
Ingroup should make the first move & 4.2 & 0.5 \\
Total & 118 & 197 \\
\hline
\end{tabular}

Whereas Croats insist on punishing the crimes committed by the outgroup, Serbs insist that each side should tackle its own culprits and are much more inclined to take a passive stand and wait for the passing of the time to improve rela- 
tions. Even though the vast majority expects reconciliation in the future (only $7 \%$ of Croats indicated that reconciliation should not take place), neither group believes that they should make the first step toward intergroup rapprochement.

These clearly different perspectives lead us to hypothesize that under such circumstances different factors may be responsible for variations in attitudes toward intergroup rapprochement within the Serb group than within the Croat group. Relations between all variables are presented in Table 4, further illustrating different patterns among the two groups.

\section{Table 4}

Correlation Between Variables, for Serbs (Above Diagonal) and Croats (Below Diagonal) in Study 1

\begin{tabular}{|c|c|c|c|c|c|c|c|c|c|c|c|c|c|}
\hline Variable & 1 & 2 & 3 & 4 & 5 & 6 & 7 & 8 & 9 & 10 & 11 & 12 & 13 \\
\hline 1. Gender & 1 & n.s. & $-.30^{* *}$ & n.s. & n.s. & $-.25^{* *}$ & n.s. & n.s. & n.s. & n.s. & n.s. & n.s. & $-.23^{*}$ \\
\hline 2. Age & n.s. & 1 & $-.22^{*}$ & n.s. & $.27^{\star *}$ & $.19^{*}$ & $.33^{* *}$ & $.24^{* *}$ & n.s. & n.s. & n.s. & $.24^{* *}$ & n.s. \\
\hline 3. Education level & n.s. & $-.28^{* *}$ & 1 & $-.19^{*}$ & n.s. & n.s. & $-.21^{*}$ & $-.23^{*}$ & n.s. & n.s. & n.s. & n.s. & $.23^{*}$ \\
\hline 4. Ethnic identification & n.s. & n.s. & $-.20^{* *}$ & 1 & n.s. & n.s. & n.s. & $.40^{* *}$ & n.s. & n.s. & n.s. & n.s. & $-.28^{* *}$ \\
\hline 5. Stressful war events & n.s. & n.s. & n.s. & n.s. & 1 & $.33^{* *}$ & $.32^{* *}$ & n.s. & n.s. & n.s. & n.s. & $-.18^{*}$ & n.s. \\
\hline 6. Traumatic war events & $-.32^{* *}$ & $.17^{*}$ & n.s. & n.s. & $.44^{* *}$ & 1 & n.s. & n.s. & $.21^{*}$ & n.s. & n.s. & n.s. & n.s. \\
\hline 7. IES & n.s. & $.16^{*}$ & n.s. & $.16^{*}$ & $.36^{* *}$ & $.35^{* *}$ & 1 & $.19^{*}$ & n.s. & n.s. & n.s. & n.s. & $-.19^{*}$ \\
\hline 8. Perception of ingroup victimization & n.s. & $.24^{* *}$ & $-.22^{* *}$ & $.41^{* *}$ & n.s. & n.s. & $.19^{* *}$ & 1 & n.s. & n.s. & $-.27^{* *}$ & n.s. & $-.55^{* *}$ \\
\hline 9. Post-war victimization & n.s. & n.s. & n.s. & $-.16^{*}$ & $.27^{* *}$ & n.s. & $.15^{*}$ & n.s. & 1 & $-.25^{* *}$ & $-.22^{*}$ & $-.33^{* *}$ & n.s. \\
\hline 10. Outgroup competence stereotype & n.s. & n.s. & n.s. & $-.23^{* *}$ & n.s. & n.s. & $-.18^{*}$ & $-.29^{* *}$ & n.s. & 1 & $.56^{* *}$ & $.30^{* *}$ & $.27^{* *}$ \\
\hline 11. Outgroup warmth stereotype & n.s. & n.s. & n.s. & $-.25^{* *}$ & n.s. & n.s. & $-.21^{* *}$ & $-.29^{* *}$ & n.s. & $.51^{* *}$ & 1 & $.36^{* *}$ & $.33^{* *}$ \\
\hline 12. Positive outgroup affect & n.s. & n.s. & n.s. & $-.36^{* *}$ & n.s. & n.s. & n.s. & $-.28^{* *}$ & n.s. & $.48^{* *}$ & $.36^{* *}$ & 1 & $.18^{*}$ \\
\hline 13. Rapprochement & n.s. & n.s. & $.20^{* *}$ & $-.38^{\star *}$ & n.s. & n.s. & $-.16^{*}$ & $-.45^{* *}$ & n.s. & $.39^{* *}$ & $.34^{* *}$ & $.54^{\star *}$ & 1 \\
\hline
\end{tabular}

${ }^{*} p<.05 .{ }^{* *} p<.001$.

The results show that ethnic identification in both groups is relatively strongly related with perceived ingroup victimization $\left(r_{\text {Serbs }}=.40, p<.001 ; r_{\text {Croats }}=.41, p<.001\right)$, suggesting that ethnic identity might be built around the belief in one's group victimhood. Thus, it is not surprising that ethnic identification is negatively correlated with intergroup rapprochement $\left(r_{\text {Serbs }}=-.28, p<.001 ; r_{\text {Croats }}=-.38, p<.001\right)$. However, while in the Serb sample ethnic identification level bares no relation to outgroup stereotypes or positive affect, among Croats stronger ethnic identification is correlated to more negative stereotype of Serbs - as less competent $(r=-.23, p<.001)$ and less warm $(r=-.25, p<.001)-$ as well as with the lack of positive affect for the outgroup $(r=-.36, p<.001)$. Thus, although among Croats the distribution of ethnic identification and perceived ingroup victimization appears skewed toward the maximum value of the scale, even such limited variability still shows meaningful correlations with other relevant constructs.

Interestingly, in the Serb sample experienced traumatic war events are not correlated to their impact nowadays, nor to the intergroup perception and relations, but are correlated to perceived post-war discrimination $(r=.21, p$ $<.05)$. Stressful war events, on the other hand, show low negative correlation with positive outgroup affect $(r=-.18$, $p<.05)$. In the sample of Croats, both stressful and traumatic war events are correlated to the impact of such events nowadays $\left(r_{\text {stress }}=.36, p<.001 ; r_{\text {trauma }}=.35, p<.001\right)$ and stressful war events are also correlated to perceived post-war victimization $(r=.27, p<.001)$. In line with the expectations, the impact of war events is (weakly) related to perceived war and post-war victimization $\left(r_{\text {war }}=.19, p<.001 ; r_{\text {post-war }}=.15, p<.05\right)$, outgroup stereotypes $\left(r_{\text {warmth }}=-.21, p<.001\right.$; $\left.r_{\text {competence }}=-.18, p<.05\right)$, and readiness for rapprochement $(r=-.16, p<.05)$. Overall, Croats' orientation towards Serbs appear more affected by experienced war trauma. It is noteworthy however that, in both groups, personal traumatic events and perceived ingroup victimization are not correlated. Perceived victimization of the ingroup seems to be more important for one's ethnic identity and for intergroup relations than any individual-level measures of victimization (personally experienced trauma or its individual psychological impact).

Finally, in both groups outgroup stereotypes outgroup affect are moderately to strongly correlated, and both aspects are also connected to individual's readiness for intergroup rapprochement. Nevertheless, whereas among Serbs stereotypes $\left(r_{\text {warmth }}=.33, p<.001 ; r_{\text {competence }}=.27, p<.001\right)$ bare stronger connection to intergroup rapprochement than outgroup affect $(r=.18, p<.05)$, among Croats positive affect $(r=.54, p<.001)$ is more strongly connected to 
rapprochement than stereotypes $\left(r_{\text {warmth }}=.34, p<.001 ; r_{\text {competence }}=.39, p<.001\right)$. However, this might be due to the ceiling effect in the positive outgroup affect among Serbs.

To explore the role of competing narratives for the intergroup rapprochement, we conducted separate regression analyses for each of the groups and investigated whether differences in perception of war and post-war victimhood, and different cognitive and/or emotional relations toward the outgroup predict rapprochement in both groups. We entered the following groups of variables: 1. Socio-demographic data (gender, age, education level); 2. Ethnic identification; 3. Traumatization (experienced stressful and traumatic war events during the war, impact of trauma); 4. Perceived victimhood (perception of ingroup victimization during the war, post-war victimization); 5. Outgroup stereotypes (competence and warmth); 6. Positive outgroup affect. Results of the final model are presented in Table 5 and Table 6.

Table 5

Standardized Regression Coefficients in the Final Step of Regression Model for Predicting Intergroup Rapprochement on the Serb Sample

\begin{tabular}{|c|c|c|c|c|c|c|}
\hline Variable & Model 1 & Model 2 & Model 3 & Model 4 & Model 5 & Model 6 \\
\hline Gender & -.18 & -.18 & -.16 & -.13 & -.12 & -.12 \\
\hline Age & -.06 & -.09 & -.08 & .02 & .04 & .03 \\
\hline Education level & .15 & .07 & .05 & .03 & .04 & .04 \\
\hline Ethnic identification & & $-.29^{* *}$ & $-.29^{* *}$ & -.09 & -.08 & -.08 \\
\hline Stressful war events & & & .08 & -.04 & -.06 & -.05 \\
\hline Traumatic war events & & & .08 & .09 & .12 & .12 \\
\hline IES & & & -.11 & -.06 & -.07 & -.06 \\
\hline Perception of ingroup victimization & & & & $-.49^{* *}$ & $-.45^{* *}$ & $-.44^{* *}$ \\
\hline Post-war victimization & & & & -.04 & .01 & .02 \\
\hline Outgroup competence stereotype & & & & & $.19^{*}$ & $.19^{*}$ \\
\hline Outgroup warmth stereotype & & & & & .09 & .08 \\
\hline Positive outgroup affect & & & & & & .03 \\
\hline$\Delta R^{2}$ & $.08^{*}$ & $.08^{* *}$ & .01 & $.18^{* *}$ & $.06^{* *}$ & .001 \\
\hline$R^{2}$ & .08 & .16 & .17 & .35 & .41 & .41 \\
\hline
\end{tabular}

${ }^{{ }^{2} p<.05 .}{ }^{* *} p<.001$.

Table 6

Standardized Regression Coefficients in the Final Step of Regression Model for Predicting Intergroup Rapprochement on the Croat Sample

\begin{tabular}{|c|c|c|c|c|c|c|}
\hline Variable & Model 1 & Model 2 & Model 3 & Model 4 & Model 5 & Model 6 \\
\hline Gender & -.09 & $-.14^{*}$ & $-.15^{*}$ & -.11 & -.13 & -.09 \\
\hline Age & .04 & .07 & .09 & .14 & .13 & .07 \\
\hline Education level & $.20^{* *}$ & .13 & .12 & .09 & .12 & $.13^{*}$ \\
\hline Ethnic identification & & $-.39^{* *}$ & $-.37^{* *}$ & $-.25^{* *}$ & $-.21^{* *}$ & -.12 \\
\hline Stressful war events & & & .01 & .02 & .02 & .03 \\
\hline Traumatic war events & & & -.05 & -.07 & -.07 & -.01 \\
\hline IES & & & -.07 & -.03 & .01 & -.03 \\
\hline Perception of ingroup victimization & & & & $-.33^{* *}$ & $-.26 * *$ & $-.23^{* *}$ \\
\hline Post-war victimization & & & & -.04 & -.06 & -.04 \\
\hline Outgroup competence stereotype & & & & & $.27^{* *}$ & .13 \\
\hline Outgroup warmth stereotype & & & & & .06 & .03 \\
\hline Positive outgroup affect & & & & & & $.36^{* *}$ \\
\hline$\Delta R^{2}$ & $.05^{*}$ & $.14^{* *}$ & .01 & $.09^{* *}$ & $.08^{* *}$ & $.08^{* *}$ \\
\hline$R^{2}$ & .05 & .19 & .19 & .28 & .36 & .44 \\
\hline
\end{tabular}

${ }^{*} p<.05 .{ }^{* *} p<.001$. 
The whole set of variables explain $41 \%$ of variance of rapprochement among Serbs and $44 \%$ among Croats. Among Serbs, the key predictor of rapprochement is perceived ingroup victimization $(\beta=-.44, p<.001)$. Those who perceive their ingroup as a victim of the war are less open for approaching the outgroup. The only other variable that uniquely contributes to prediction of rapprochement is the stereotypical view of Croats as competent $(\beta=.19, p=.06)$. However, this effect is rather small and marginally significant. All other variables become irrelevant in this context. On the other hand, among Croats - the majority group that is also less ready for reconciliation, predictors of intergroup rapprochement are somewhat different (Table 6). Rapprochement is fostered mostly by positive outgroup affect $(\beta=.36$, $p<.001$ ) while perception of the ingroup as a victim negatively predicts intergroup relations. Finally, higher education level also contributes to readiness for rapprochement, although its effect is rather small and unstable $(\beta=-.13, p<.05)$.

Altogether, the results show that, when other factors are taken into account, individual victimization, i.e. number of traumatic experiences and their psychological impact, is not predictive of intergroup rapprochement in either group. In the same vein, recent post-war victimization plays no role in intergroup relations. Perceived ingroup victimization, on the other hand, does.

The role of ethnic identification in predicting rapprochement among Croats and Serbs is rather interesting. Ethnic identification predicts rapprochement until a group-specific variable is entered. For Serbs it is perceived ingroup victimization, and for Croats positive outgroup affect. However, this difference might be a reflection of the group-specific ceiling effect in the perceived ingroup victimization among Croats, and in the positive outgroup effect among Serbs, visible in the descriptive statistics shown in Table 1.

Interestingly, after controlling for the traumatization level, different factors predict rapprochement within the two groups. In the lower status group, i.e. Serb ethnic minority, cognitions (perceived collective victimhood and stereotype of Croats as competent) are more predictive than the affect. This is in line with other findings showing that positive emotions about the other community are not necessary for people to forgive the outgroup for past wrongdoings (Tam et al., 2007).

To test whether the predictors of rapprochement indeed differ for the two groups we conducted moderation analyses using PROCESS (Hayes, 2018). Group membership (Croats vs Serbs) was examined as a moderator between several predictors (perceived ingroup victimization, post war victimization, stereotype of outgroup as competent and positive outgroup affect) and rapprochement. A significant interaction was found only between positive outgroup affect and group membership, $B=.19,95 \%$ CI $[.02, .36] p<.05$. The conditional effect of positive outgroup affect on rapprochement showed corresponding results, for Croats .38, 95\% CI [.29, .47] $p<.01$; for Serbs .19, 95\% CI [.04, .34] $p<.05$. As positive outgroup affect increases, readiness for rapprochement also increases, but more so for Croats than for Serbs, whose average scores are higher to begin with. Thus, at high positive affect towards the outgroup readiness for rapprochement is similar for both groups, but at low levels of positive outgroup affect Serbs are more inclined to rapprochement than Croats, corroborating the IET (Figure 1).

Figure 1

Results of Moderation Analysis of Group Membership (Croats vs. Serbs) as a Moderator Between Positive Outgroup Affect and Intergroup Rapprochement

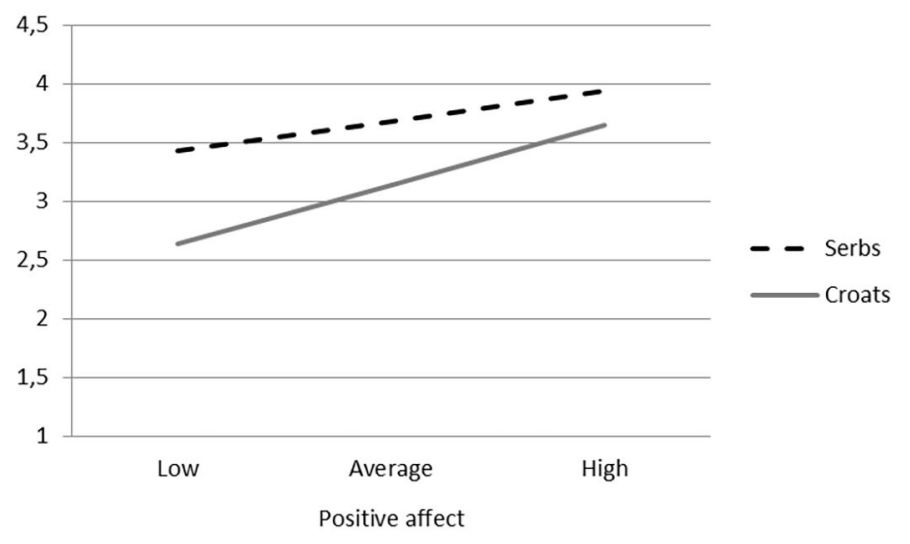


In order to contribute further to understanding multiple perspectives in post-conflict settings, we explored the specific profile of community members who endorse minority positions, i.e. alternative narratives of the conflict. Therefore, we focused on those participants in each group who gave alternative (i.e. other than dominant) answers on the item referring to competitive victimhood. Unfortunately additional analysis proved possible only for the Croat sample (Table 2), where 37 participants answered „both groups were equal victims”. In the Serb sample only 10 participants differed from the dominant narrative, out of which 5 considered Croats greater victims, and 5 considered Serbs greater victims, which did not allow for further analyses. Hence, we turned our focus to Croat subsample and wanted to determine if these 37 Croats differ from the majority of their ingroup by some socio-demographic characteristic. We found only two marginally significant differences. First, we found gender differences suggesting that among those holding different narratives of the conflict there are more women $\left(\chi^{2}=3.03, p=.08\right)$. Second, it seems that among those holding alternative narratives of the conflict, those who lived in Vukovar during the war are over-represented $\left(\chi^{2}=3.14, p=.07\right)$. Thus, it seems that women may be more open for different interpretations than men, and that Croats who actually witnessed the war in Vukovar first-hand also have an experience of people from both sides suffering and losing loved ones. However, the effects are small $(\mathrm{Phi}=0.22)$ and should be explored further in future studies.

In line with previous data, those participants who hold alternative narratives of the intergroup conflict do not differ from the rest of the Croat sample in the level of traumatization, nor the impact that war experiences continue to have today on them. However, they identify less strongly with the ingroup, $t(196)=5.32, p=.001$, and perceive more discrimination in the post-war period, $t(196)=2.42, p=.016$. Furthermore, those participants declared more positive affect toward the outgroup, $t(196)=4.78, p=.001$, consider the outgroup members more competent, $t(196)=4.08$, $p=.001$, and warm, $t(196)=2.42, p=.016$. As expected, participants who hold alternative narrative of the intergroup conflict also show significantly greater readiness for intergroup rapprochement than their ingroup peers who embraced the dominant narrative, $t(196)=3.53, p=.01$.

\section{Study 2 - Transmitted Narratives in the Second Generation Youth}

In Study 1 we established the broader ideological context in the local postwar community and showed that war-related understandings are indeed different in the two conflicted groups, Croats and Serbs from Vukovar, and that these narratives represent an important obstacle for intergroup rapprochement. However, it is an open question whether such narratives persist among youth born after the war and, if they do, how the post-war generation navigates in this context and makes sense of the narrative(s) it is exposed to. Those adolescents grew up in the atmosphere of a divided city, where formerly belligerent groups live parallel lives with no, or only occasional, contact between communities (Ajduković \& Čorkalo Biruški, 2008; Reidy et al., 2015). The official commemorative practices confirm the dominant (majority groups') narrative of the war and victimhood, and ignore the victims of the minority group. If the "others" are excluded from the category of victims in the dominant narrative of the past conflict, we are interested in the consequences of such denial (vs acknowledgement) of collective victimization for the second generation youth. However, family memories might tell different stories and oppose the dominant narrative of the war, as suggested by Popov and Deak (2015). Therefore, in study 2 we wanted to explore if alternative narratives exist among the adolescents (especially minority adolescents) and, if so, whether they find a public space to be told, or if they are silenced and neglected.

\section{Method}

Six focus groups with Croat $(N=18)$ and Serb $(N=24)$ adolescents aged 11, 13, and 15 years were conducted in 2010 in the city of Vukovar. A more detailed description of the sample is provided in Reidy and colleagues (2015). The focus group as a method appropriate for studying collective experiences (Denzin \& Lincoln, 2005) was used to explore how the second generation of war survivors perceive and interpret their ingroup narratives on war, and how these narratives relate to their understanding of intergroup relations and rapprochement. In order to answer these research questions we unfolded the adolescents' narratives based on their conversation about war issues within their families and in the wider 
community, and the perceived possibilities of Croats and Serbs to reconcile. The focus groups were held in a local hotel and led by researchers with an extensive experience in working in the Vukovar community, especially with the youth. Group sessions lasted up to 90 minutes, and participants were modestly compensated for their effort. All discussions were taped and transcribed verbatim. Transcripts were then coded and analysed using a thematic analysis approach (Braun \& Clarke, 2006). The study was approved by the Institutional Review Board of the Department of psychology, University of Zagreb.

\section{Results}

The results are organized around two major themes on how the adolescents perceive, interpret and understand: (1) the recent past through the war-related narratives they hear, and (2) possibilities for improving intergroup relations. The second author content analysed the transcripts guided by the focus groups questions and by using the thematic analysis approach (Braun \& Clarke, 2006). A process of open coding was used in order to identify major categories and themes. We were actively looking for elements indicating how the war narrative was constructed and transmitted (i. e. if adolescents show interest in the issue when they interact with their social environment, and with whom they talk about the issues), and their understanding of the possibility for reconciliation (i. e. if it is possible, who is more likely to reconcile, and what would be indicators of reconciliation) $)^{2}$. The emerging understanding of the war-related narrative included two distinct content categories, and the theme of reconciliation comprised three content categories. The content of themes and categories with corroborating primary data are provided in Appendix B. An initial written summary of content categories and corroborating primary data was discussed among the three authors until reaching consensus about the nature of categories and corroborating data. Quotations from the focus groups discussions are used in order to illustrate how the analytic interpretations are rooted in the data (Elliot et al., 2018). They provide both typical findings and opinions that diverge, indicating inter- and in-group differences.

\section{Transmission of War-Related Narratives: Young People's Sense-Making of the Recent Past}

Focus group discussions revealed that young people are typically exposed to one-sided perspectives of the war, mostly within their own family and by the media, with little space for critical examination or debate. Serb respondents mostly deny any interest in the topic and claim they do not talk about the war in their families. Only older Serbian teenagers mentioned that they have a few peers who are interested in discussing war-related issues. Unlike them, Croat participants' interest is unequivocal - they all reported that they are interested in the issue. However, their experiences in talking about the war are more divergent: with no clear age pattern, some participants explored these issues with their family quite often, while others did not. References to the family's war-related victimisation appeared in discussions of Croat participants as an explanation for both why a family does or does not share the story of war. The following statements illustrate these two very different experiences well.

Well, my mother had a brother who died in the war. So she doesn't like to talk about it; my grandma, she's constantly in black, she can't wear another color. $(C-F-13)^{3}$

My dad was a defender $r^{4}$ and he told me there had been really all kinds of disasters and stuff. (C-F-15)

... My dad is a war veteran. I asked him if they ever laughed there, or if they were just... He said they did, but they still fought and everything. (C-F-11)

2) In the discussions with the youth we used the term "reconciliation" when referring to possibilities for improvement of intergroup relations because these participants were more familar with this expression which is more common in the public discourse. This is the reason why we use "reconciliation" when describe qualitative study findings even though we elaborated previously why we consider the term "intergroup rapprochement" to be more accurate when referring to post-conflct intergroup relations.

3) ID of a participant is given in the parenthesis indicating his/her ethnicity (C or S), gender (F or M) and age.

4) Meaning Croatian soldier who fought in the war. 
However, regardless whether or not families share the stories about the war, memory on Croat victimhood is nurtured through public events and memorials.

And we, when it was The Day of the Fall of Vukovar, we went to Borovo-komerc, there was an organised prayer and people from the city council laid down the wreaths, and then we all went to church for the mass. (C-M-11)

Another Croat participant described a typical commemoration event:

We went from Velepromet to Vodotoranj ${ }^{6}$, lighting candles with our teacher... It was really nice. And later that day we went from the hospital to the cemetery, and we could see the candles we lit. (C-F-11)

In the Croat group, victimization is an important pillar of how the narrative of war is transmitted to the second generation: explicitly, by emphasizing (personal and community) victimization, and implicitly by refusing to talk about it because it is too painful and too disturbing. Similar strategies of intergenerational transmissions have been shown in other settings, e. g. with the offspring of Holocaust survivors (Braga, Mello, \& Fiks, 2012). Either way, young people obviousy have received a clear message about which group was a (greater) victim of war. This narrative is well synchronized in public discourse and supported by a variety of social actors and sources of influence (see Reidy et al., 2015). Importantly, school did not appear in conversations as an important source of information about the war narrative in either of the groups, although a few Croat participants (and none among Serbs) described very extensive commemoration practices that schools are involved in, when observing important dates and events from the recent war. Obviously, the narrative is transmitted more by "observing" the history than by actively teaching it. In this way, school is excluded as an important source of information and public site for critically examining history, as detected recently also in some other European countries with difficult past issues, such as Finland (Wolnik et al., 2017). Moreover, by doing so the school does not participate in the process of wider societal repair (Weinstein, Freedman, \& Hughson, 2007). Interestingly, peers were not mentioned very often as interlocutors in conversations about the war, especially not out-group peers. Nevertheless, there are rare examples of stories exchanged between Croat and Serb adolescents, showing a sign that the younger generation might be more ready and willing to question hegemonic and conflict-supportive beliefs of their respective in-groups (Bar-Tal, 2013). An excerpt from the focus groups with 13-years old Croat adolescents illustrates how peers from the two groups could peacefully talk through the issues:

C-M-13: Well, sometimes when I talk with my friends, who are of Serbian nationality, then sometimes we debate about it, but we never argue, we just talk normally and then I ask my mum or dad.

Moderator: So you talk with your friends who are of Serbian nationality...

C-M-13: Openly.

Moderator: And how does that conversation go? What do you talk about, what do they talk about?

C-M-13: Well, mostly we talk about why they killed each other in the first place and I don't get it, if we get along, why couldn't they and why did it [war] even start.

Moderator: Is there a difference in the way you talk about it and how they talk?

C-M-13: Not really.

While, overall, the findings may create an impression that the Croat narrative is monolithic and unquestionable, an active search for different examples demonstrated that there are different, although not very loud and open, voices

5) A site in the city strongly associated with war.

6) Sites and objects in the city strongly associated with war. 
among young people. While talking about war narratives as a source of dispute among young Croats and Serbs, a Croatian 13-years old girl explained:

C-F-13: Well, there are some who think it's none of their business, mostly that they don't know how it was and that there's no point in arguing over that now, but some think exactly the opposite, that it should encourage us to argue with them [i.e. with Serbs], I don't know.

Moderator: What do YOU think?

C-F-13: Well I think it makes no sense, since not one of us was born, so no one knows what it was like then.

Unlike their Croat peers, Serb participants tend to ignore the issue. They claim neither talking about the war (in families and among themselves), nor being interested in the subject. Older adolescents are particularly explicit about this strategy of coping with the past:

I am not interested in this stuff... And even when it is mentioned, mostly they [i. e. Croat peers] are the ones who know everything. It's mostly them, they were told everything and they know everything. And us, there are some of us who are not the least interested in it. (S-F-15)

However, silencing the past may be a way of how (Serb) parents, on the one hand, protect their children from personally painful stories and, on the other hand, discourage them from asking questions because the answers may not correspond with the dominant and one-sided (Croat) narrative that is publicly endorsed and acknowledged.

... In my house they always teach me not to live in the past, meaning to live what's happening now, because what happened before, it's not my fault but of the generations before. So they don't tell me anything and they try that I don't find out anything because it's better, I could get traumatized, I don't know, if someone talks to me like that, it's better like this when I don't know. (S-F-13)

Nevertheless, Serb respondents feel provoked by the dominant (Croat) narrative about the war, especially the one presented by the media, and try to confront and question it. Moreover, it seems that young Serbs are in possession of a counter-narrative; however, this narrative is not clearly expressed and it maybe not even be constructed coherently. Instead, it includes some opposing views and different interpretations that are difficult to bring in as legitimate in the dominant discourse about the recent war. As one of the Serb participants said:

Yeah, in a way they provoke Serbs who live in Croatia. They always show Serbs and blame us Serbs like we were guilty for something. But then, in a way it might not be true. We're all equally to blame. $(S-M-15)$

The same statement illustrates also the narrative transmitted to the Serb adolescents and corroborates the quantitative data presented in Study 1, on differences in perception of victimhood and responsibility for the war in two formerly belligerent groups. Moreover, older Serb respondents seem to be especially bothered by reminders of war and the past by the media, believing that this is something that contributes to further divisions between Croats and Serbs:

Because they remind us of it every day and they are constantly airing these footage on the TV. And now they are constantly talking about those trials and that is mostly what incites young people ... Those media which are constantly talking about it and, so to say, they produce even more of this dissent between the Croats and the Serbs. (S-M-15)

Let them [i. e. Croats] respect their own. And I mean we do know what happened here and how many people died and everything. We're not asking them to forget about it or something, but they shouldn't show it so much in the media. (S-F-15)

And although the Serb adolescents deny any talking about the war within their families, the other side of the story, confronting the dominant (Croat) narrative, has been provided by familiar adults if not spontaneously than as a 
response to media portraits and accounts of the past and war events. An excerpt from the focus group with older adolescents illustrates this nicely:

Well, it was also in Istraga [Investigation, name of a TV show], that they were showing those conflicts in some way... it was always the Serbs who were worse. When I watch it with someone older who knows some of those things they say that they aren't true. And they only increase this hatred between people with these shows. (S-F-15)

Altogether young Croats accept the dominant narrative of their group indicating Croats as victims of Serbian aggression, whereas for Serbs the war narrative is less straightforward. Serb adolescents clearly show distrust towards media accounts. However, from their discussions it is less clear how they build up and construe different explanations of the past and where their interpretations come from. The Serb narrative is not openly talked about, it is not present in the media, and families mostly send the message that the war should be ignored and forgotten, leaving Serb adolescents with an unclear idea of how to receive, question or confront the majority's hegemonic narrative. The parcels of information they pick up every now and then do not allow them to form a coherent counter-narrative of the war. Such segmented information, and even more what is not being said, may indicate that the war narrative the Serb adolescents receive and use for sense-making is certainly different from the dominant one.

\section{Possibilities for Intergroup Reconciliation: Adolescents' Understanding of the (Common) Future}

Both Croat and Serb adolescent participants see the war as the major reason for disturbed intergroup relations. However, there are differences in how members of the two groups perceive and understand possibilities for intergroup reconciliation. Most often the participants see passing of time as a necessary condition for improving intergroup relations. Although the focus groups were conducted 15 years after the end of the war, the participants, especially Croat adolescents, obviously accept and internalize the narrative that the "war wounds are still fresh" and call for more time to make intergroup rapprochement and reconciliation possible. They often doubt that the first generation of war survivors is capable of improving intergroup relations and put more hope in the new generations.

Maybe there still hasn't passed enough time since then, so everyone is still worked up about it; maybe after enough time has passed, then it could be done. [ ... ] Well I don't know, maybe this generation of defenders, when all of this is gone, I mean, when they die, how should I say... And then when this new generation comes, which hasn't been in the war, then they might, but I don't know. (C-M-15)

Moreover, some Croat adolescents clearly see lack of motivation in their (ethnic) community to proactively improve intergroup relations and find reasons for this passivity in the recent war history. Nevertheless, though not optimistic about current possibilities, there is some hope for future generations. However, young participants from neither ethnic background see their own generation as an actor of reconciliation. "The younger ones" they talked about as a future potential are typically some abstract younger generations, in a distant future:

I don't think [Croats] would want to do something. I think that the Serbs attacked them, and the Croats did not attack them, they wanted to take our town, we didn't want to take theirs. [ ... ] I don't think anybody would want that [i. e. make a move towards reconciliation] any more. I think that the quarrels won't stop, it won't get better here, perhaps between the younger ones, but the older ones as I said, they won't. (C-F-13)

Similarly, some Serbian participants are doubtful about possibilities for reconciliation and about that passing of time will help because of the losses.

I think they [i. e. Croats and Serbs] can't [reconcile]. Because some people have such a past, they've lost their loved ones and that they will never forget and then they just simply couldn't reconcile with these other people that, they think, killed people they were close to. (S-F-13) 
Though many Serb adolescents have little faith in reconciliation, the following excerpt from the focus groups with 15-year-olds illustrates diversity in their opinions about (possibilities of) reconciliation, even though many of them do not believe that the idea of reconciliation could prevail:

F-01: They could [reconcile].

Moderator: How?

F-02: But they no longer want to.

M-01: To forget about the past.

F-01: Well they don't want to anymore, you can see how it is; and there are less of those who socialize [with the out-group]. There are more of those who don't socialize. Who don't want to. And that's that...

F-03: And even if they want to, even if the majority [of people] wants to, there's always that one individual who doesn't want to, who is opposed, and who spits on the war. I think that they will never be able to completely reconcile with each other, nor will it be that no one has anything against anyone...

Even more, some of the young Serbs recognize that transmission of the war narrative could be a serious obstacle in the process, and talk about Croats not being able to let go the stories of war:

[Possibilities for improving intergroup relations are dependent on influences of] ... environment, media and parents. I believe our parents talk to us more rarely about such things. But, for example, [Croat] parents who were in that war and who have something against the Serbs and who will always have something against the Serbs and who tell their children that, they will probably also grow some sort of hatred inside of them and it will always stay with them... Whether they are in good relations or in bad relations, there will always be something holding back... (S-F-15)

And the other girl corroborates this perspective:

And then they [Croats] will pass it onto their children, from generation to generation. (S-F-15)

Discussion in focus groups of 15-year-olds revealed that a few young Serbs have a difficult time understanding why Croats insist on remembrance of the recent past. An excerpt describing different strategy (of remembrance) of Belgrade ${ }^{7}$ and Zagreb ${ }^{8}$ illustrates nicely a need for acknowledgement in the Croatian discourse and a need for forgetting, and not dealing with the past, in the Serbian perspective, even when the adolescents are interested in what had happened:

I don't know, I've got relatives in Belgrade, and over there people also don't talk, they've never talked nor reminded themselves of it [i. e. of the war], so it's different in Belgrade, it's different in Zagreb and in any other Croatian town. And in fact I asked them how it was back there, what was the way of life, if it was different over there [i. e. in Serbia]. They don't want to remember anything. And yet here, constantly, the only thing they show on the TV is about those, like, war criminals, about how they have to capture them and bring them to trial ... nothing else. (S-M-15)

Some Serb adolescents talked about the necessity to recognize the Serb victims, and not only the Croat ones, in order for Croats and Serbs to be able to reconcile. A challenging excerpt from the discussion of 13-years-olds Serbs showing a child-naïve perspective reveals their very different understanding on war victimization, and how it should be recognized in order to improve intergroup relations:

7) The capital of Serbia.

8) The capital of Croatia. 
And the street signs are also offensive. There is a street of The Croatian Defenders, I think that street should be renamed because the Serbs also were in that war and a lot of Serbs died, the same as Croats. The street names should be changed, because some defenders even got their names on tiles and their monuments, and we didn't get a thing, this is something that should be changed. (F-01)

[It could be renamed as the street of the] Croatian and Serbian defenders. (M-01)

Here, this can be done ... a monument [for those who got killed on the Serbian side] (F-01)

However, some participants disagreed and pointed out why this solution was far from possible.

Well that [a monument] should be in Serbia. (M-02)

Yes, that should be in Serbia... Because I think that, in Serbia for example the Serbs wouldn't build a monument to Croats that got hurt in that war, and the Croats wouldn't likewise do it for Serbs, so it's mutual and it can't be changed. (F-02)

Another important aspect that Serb adolescents, unlike their Croat peers, see as critical for reconciliation is equality and absence of any discrimination based on ethnicity. Interestingly, the most explicit account of this prerequisite came from the youngest participants, corroborating that even preadolescents are well aware of intergroup inequalities in their social environment (see Ruck, Mistry, \& Flanagan, 2019). A young Serb participant explained:

Well, yes, sometimes, in some companies, for example, my mom works for the tax department, so she knows about all these companies, and anyway, this one Serb opened up his own company and he only employs other Serbs, he doesn't want anyone else, because he has good relationships with all these people, and he knows all of them, and it's the same on the Croatian side. [...] They would only hire someone if s/he wants to be a cleaning person or something like that. (S-F-11)

Unlike this perspective, to some young Croats the concept of minority rights has been transmitted as an obstacle for reconciliation:

My mom also thinks that, if those Serbs stay here, and educate their children in Serbian language, and in a few years, if they'll still be living in Vukovar, their children will, if they only learn Serbian [...], and this is Croatia, they should be speaking Croatian. (C-M-11)

In sum, the Croat adolescents' narrative on the war, as described by our participants, is homogenous and built around the perception of strong and exclusive victimization in the recent war. Unlike Croats, the young Serb participants tend to cope with the legacy of war by silence, overwhelmed by the Croatian public and official narrative and, in a few instances, by mentioning the necessity to have a social space for acknowledging Serb victimization as well.

These data suggest that the second generation youth, born after the war, sees little possibilities of rapprochement and reconciliation between Croats and Serbs in Vukovar. The adolescents believe that a necessary condition for reconciliation is passing of time. In their view, time is of relevance because as long as people with traumatic war experiences are alive, reconciliation is impossible. Their view is very pessimistic, at least for their generation - almost as if they would betray the ideals of their parents if they show readiness to reconcile.

However, despite of converging ideas that reconciliation is impossible, some group differences do exist - while for Serb participants the necessary precondition for reconciliation seems to be forgetting the past, the Croat adolescents' narrative considers remembering the past as crucial for their sense of identity. Like adults, Serb adolescents seem to be more open to the idea of reconciliation, but are pessimistic regarding its actual probability. This difference reflects the different status of the two groups in the society. Croats as a majority group do not feel the need to reconcile or be proactive in rapprochement. Thus, their narrative is more homogenous insisting on them as victims who have turned into victors, but at a very high price. Serbs, on the other hand, have a more diverse and vague narrative. Their position as a minority leaves them with envy while the dominant narrative depicts them as perpetrators, denying them the right to the victim status. This explanation is corroborated by the finding that only members of the minority status group proposed intergroup equality as a way of reconciliation, while (some) majority members referred to minority rights as 
an identity threat. Rare voices representing diverging perspectives were given, almost in a by-the-way manner, without a real capacity to challenge the dominant (majority) narrative.

\section{General Discussion}

This study's findings support the view that attitudes toward intergroup rapprochement are driven more by processes of collective sense-making than by concrete experiences of victimisation. Thus, we challenge the notion that personal or collective trauma in itself is sufficient to explain barriers to intergroup rapprochement. Rather, accepted narratives about the conflict are most important for people who feel strongly about their group.

The past constantly teaches us (not very effectively though) that silencing discrepancies in historical narratives of intergroup conflicts, and giving one side a monopoly on „the truth“, is not a way of reaching a lasting peace. At times of instability and uncertainty, even minor events can be perceived as a real or symbolic threat to the ingroup, triggering ethnocentrism and nationalistic views when the alternative narratives reappear, which can have serious consequences for intergroup relations. Something similar happened after the fall of the communist regime in Yugoslavia, when alternative (silenced) narratives of WW2 resurrected and fuelled animosity towards the outgroup by nationalists from all sides (Bar-Tal \& Čehajić-Clancy, 2014; Bobinac, 2015). After the Yugoslav wars (including the Homeland War in Croatia), ethnic identity became a highly salient part of people's self-concept. When that ethnic identity is strongly connected to a narrative that presents the group as a victim, i.e. when people believe that they suffered because of their ethnic identity, it becomes easy to exploit it to fuel animosity towards the „guilty“ outgroup and to disregard transgressions by one's ingroup. This could make the reconciliation process extremely difficult (Bar-Tal \& Čehajić-Clancy, 2014; Čorkalo Biruški \& Ajduković, 2016).

In this paper, we tackled the role of opposed narratives as potential obstacles for intergroup rapprochement. Our findings contribute to the growing literature looking at narratives of the war and collective victimhood as important factors that inhibit intergroup rapprochement after a serious intergroup conflict (for a review see Bilali \& Vollhardt, 2019). It seems that both Croats and Serbs are stuck with one narrative of the war that is mostly accepted within each group, as well as with a strong belief that a victim cannot be a transgressor at the same time. Moreover, perceived ingroup victimization is strongly related to ethnic identity in both groups, which suggests that specific war narratives are already incorporated into respective group identities, leaving little space for different interpretations. In line with that, among Croats (but not Serbs), ethnic identity and perceived ingroup victimization are also correlated with a lack of positive affect toward the outgroup. Croat identity is actually built on the collective trauma of a defensive Homeland War. Thus, for Croats as the majority status group this is an emotional issue connected to disliking and distrusting the outgroup. Serbs as a minority group cannot afford to disrespect the majority group, as improving their status requires acknowledgment from the majority. Thus, they are more interested in rapprochement and in finding ways to persuade the outgroup to listen to their side. However, their identity is based on the belief that both groups were equal victims, which directly opposes the narrative of the majority group. The more they believe that their group was a victim in the war, the less willing they are for rapprochement with the group who considers them as perpetrators. Hence, as clearly shown in the qualitative data, for Serbs, one way of coping with their low social status may be forgetting about the past. This tendency has also been found in recent quantitative study with adults showing that more than one fifth of Serb respondents from the war-affected areas (compared to only 5 percent of Croats) did not endorse any memory-keeping practices related to the war (Kardov, Lalić, \& Teršelić, 2010). This difference runs counter of the notion that the adolescents are generally overloaded by war memories that overshadow current problems, such as unemployment or mass depopulation (Močnik, 2019). Rather, we believe that this group difference shows that Serb adolescents resorts to silence, as they are neither willing to accept the dominant narrative nor able to contest it.

Overall, the findings suggest that enhancing readiness for rapprochement among Croats and Serbs might be a challenging task, as outgroup distrust originates from their status as war victims, which represents a significant part of both Croat as well as Serb identity. Nevertheless, scarce different voices do exist. They indicate that a slightly different narrative that includes empathy at least for civilian outgroup victims, might present a solid foundation for intergroup rapprochement (in line with IET). Although the situation is grim, we believe that changing the circumstances that 
maintain envy among lower status group may contribute to a better outgroup perception (e.g. lowering the post-war inequalities and discrimination), as suggested by the SCM. On the other hand, the lack of positive affect toward the outgroup among part of Croats might be overcome by ensuring positive intergroup contacts. However, until such interventions take place, the prospects of reconciliation are pessimistic. This is further supported by qualitative data showing that the question of collective victimhood still poisons intergroup relations with the second generation, born after the war. Today's adolescents see little hope that current divisions can be overcome, leaving it to the future generations to try. We believe that the issue of opposed narratives of the war and group victimization, if they remain unresolved, can represent a source of new intergroup conflict, a spark that can easily ignite the conflicting sides.

Why is it so difficult to overcome these contested narratives in a community that was integrated and functional only about 30 years ago, before the war? We believe there are several reasons for perpetuating opposed narratives. One factor is the ethnically divided community itself, as it prevents people from coming in contact with different perspectives. Children living in a divided town without having contact with their peers from the other ethnic group do not have an opportunity to reflect on the past, to discuss it across sides, or at least learn that there are different narratives. The only times when they encounter an opposed narrative is during an intergroup peer conflict when it's used to point a finger at the outgroup as a whole, and call for its collective guilt. Alternative narratives of the conflict among adolescents hardly exist, and rare voices representing different perspectives appear inconsistent and vague, showing no real capacity to challenge the dominant group narratives. As our results show, although people were highly traumatized during the war, it is not concrete events or personal traumatization that prevent rapprochement, but rather perceived (group) victimhood, which is connected to unreadiness for more amicable relations with the outgroup. Hence, our results contribute to the growing literature showing that victim beliefs may have a detrimental role for post-conflict intergroup processes of forgiveness and reconciliation (Noor, Brown, Gonzalez, Manzi, \& Lewis, 2008; Noor, Brown, \& Prentice, 2008); for a review see Vollhardt, 2012). Furthermore, political elites of both sides do not invest efforts in ensuring rapprochement, but rather actively (through the critical role of mass media) perpetuate the status quo that encourages hegemonic war narratives and nationalisms as a dominant form of national attachment.

So, in such a context of already rigid conflict supporting beliefs, where media space is being used to assure that society (ingroup) members would adhere to the dominant narrative, and where people are indoctrinated from early childhood on, via societal institutions and media, what can be done to foster intergroup rapprochement?

Following the work of Vollhardt and colleagues (Bilali \& Vollhardt, 2019; Vollhardt, Mazur, \& Lemahieu, 2014; Vollhardt \& Twali, 2016) we believe that even in such circumstances several types of interventions, in addition to intergroup contact, might be helpful. First, interventions focused on making personal identity more salient than group identity, because group identity is heavily saturated with feelings of ingroup victimization and acceptance of the dominant ingroup narrative of the past, and leaves little space for alternatives. Contact interventions that target adolescents and children of specific skills or interests (e.g. singing, sports, robotics etc.) and regardless of their ethnicity would be most welcome, as it would offer strengthening of the personal skills and identity and re-categorising group identity in such a way that it is more grounded on specific skills and not on ethnicity (e. g. Hughes, Turner, Blaylock, \& Jost, 2020).

Second, introducing appropriate civic education in schools, and training teachers in specific methodologies to foster a culture of openness and understanding among students, would be a big step in a promising direction. Furthemore, providing adolescents with accurate information about the war when teaching the country's history and encouraging critical thinking and discussion could enable them not only to understand the different interpretations of the war and learn to tolerate different views, but possibly also to learn from what happened and prevent recurrence in the future (Psaltis, Carretero, \& Čehajić-Clancy, 2017).

Third, interventions should aim at changing commemorative practices to make memory "functional" within a divided society (McDowell \& Braniff, 2014). As suggested by McQuaid (2015), remembrance practices are established to empower the present and to imagine the future, and as such they often become sites for the advancement of nationalism. Indeed, contemporary state practices of remembrance in Serbia, Croatia, and Bosnia, are mutually exclusive and continue to be barriers to rapprochement (Subotić, 2013). Hence, new commemorative practices should aim at the acknowledgment of outgroup narratives, i.e. outgroup victimization. Recent experimental studies showed that reading about the acknowledgment of outgroup suffering (vs. reading about outgroup's denial or a control group) resulted 
in greater willingness for reconciliation with the outgroup among different conflicted groups (Hameiri \& Nadler, 2017; Iqbal \& Bilali, 2018; Vollhardt, 2015). The final goal of such interventions should be to form inclusive victim consciousness (see Vollhardt, 2015), which should result in conciliatory attitudes, and willingness to compromise. As among both groups in Vukovar there were many civilian victims, the first step in this direction could be to acknowledge the civilian victims of war, regardless of their ethnicity, and organize joint commemoration for the victims. Such inclusive politics of remembrance could facilitate rapprochement.

In conclusion, we believe that the preservation and free circulation of diverse memories and narratives in the public space is the main challenge for the future. Even though in Vukovar a media-based public education campaign on diverse perspectives is an unrealistic goal, raising awareness of multiple narratives is still possible on a smaller scale. One example is the RECOM 9 initiative focusing on establishing the facts about all the victims of the war. Another such example is the organisation Documenta, a center for dealing with the past, which is dedicated to establishing factual truth about the war and gathering different testimonies, thereby contributing to shifting the discussion from the level of dispute over facts towards a dialogue on various interpretations of the facts. Finally, some local organisations encourage and practice intergroup cooperation and are dedicated to promote more inclusive narratives and build more inclusive social climate, especially among the adolescents. Dealing with diverse perspectives, teaching children to discuss and rethink their positions, instead of silencing alternative narratives, may in the long run foster collective resilience, and hence represent a more promising way to achieve lasting peace and stability.

Funding: The Study 1 described in this paper was supported by the Ministry of Science of Republic of Croatia, grant number 130-1301422-1418 and Study 2 was supported by the University of Notre Dame, grant number 370958-30145-20.

Acknowledgments: The authors have no support to report.

Competing Interests: The authors have declared that no competing interests exist.

\section{References}

Ajduković, D., \& Čorkalo, D. (2004). Trust and betrayal in war. In E. Stover \& H. Weinstein (Eds.), My neighbor, my enemy: Justice and community in the aftermath of mass atrocity (pp. 287-302). Cambridge, United Kingdom: Cambridge University Press.

Ajduković, D., \& Čorkalo Biruški, D. (2008). Caught between the ethnic sides: Children growing up in a divided post-war community. International Journal of Behavioral Development, 32, 337-347. https://doi.org/10.1177/0165025408090975

Baillie, B. (2019). The Dudik Memorial Complex: Commemoration and changing regimes in the contested city of Vukovar. In M. Sørensen, D. Viejo-Rose, \& P. Filippucci (Eds.), Memorials in the aftermath of armed conflict: From history to heritage (pp. 183-227). London, United Kingdom: Palgrave Macmillan.

Bajruši, R. (2018, October 15). Što je prešućeno na subotnjem prosvjedu u Vukovaru? [What was not said at this Saturday protest in Vukovar?]. Jutarnji list. Retrieved from

https://www.jutarnji.hr/komentari/sto-je-presuceno-na-subotnjem-prosvjedu-u-vukovaru-za-aboliciju-srpskih-pobunjenika-nijeodgovoran-andrej-plenkovic-nego-franjo-tudman/7940938

Baliqi, B. (2018). Contested war remembrance and ethnopolitical identities in Kosovo. Nationalities Papers, 46, 471-483. https://doi.org/10.1080/00905992.2017.1375906

Banjeglav, T. (2012/2013). (Ne)kultura sjećanja: uloga memorijala i komemorativnih praksi u post-konfliktnoj obnovi društva [(Non) culture of memory: The role of memorials and commemorative practices in the post-conflict reconstruction of society]. In E. Bužinkić (Ed.), Rad na suočavanju s prošlošću: priručnik za organizacije civilnog društva (pp. 50-58). Zagreb, Croatia: Documenta.

Bar-Tal, D. (2013). Intractable conflicts: Socio-psychological foundations and dynamics. Cambridge, United Kingdom: Cambridge University Press.

9) The acronym RECOM stands for the Regional Commission Tasked with Establishing the Facts about All Victims of War Crimes and Other Serious Human Rights Violations Committed on the Territory of the Former Yugoslavia from 1 January 1991 to 31 December 2001. 
Bar-Tal, D., \& Čehajić-Clancy, S. (2014). From collective victimhood to social reconciliation: Outlining a conceptual framework. In D. Spini, G. Elcheroth, \& D. Corkalo Biruski (Eds.), War, community and social change: Collective experiences in the former Yugoslavia (pp. 125-136). New York, NY, USA: Springer.

Bar-Tal, D., \& Halperin, E. (2011). Socio-psychological barriers to conflict resolution. In D. Bar-Tal (Ed.), Intergroup conflicts and their resolution: Social psychological perspective (pp. 217-240). New York, NY, USA: Psychology Press.

Bar-Tal, D., \& Salomon, G. (2006). Israeli-Jewish narratives of the Israeli-Palestinian conflict: Evolvement, contents, functions and consequences. In R. I. Rotberg (Ed.), Israeli and Palestinian narratives of conflict: History's double helix (pp. 19-46). Bloomington, IN, USA: Indiana University Press.

Bekerman, Z., \& Zembylas, M. (2012). Teaching contested narratives: Identity, memory and reconciliation in peace education and beyond. Cambridge, United Kingdom: Cambridge University Press.

Bekerman, Z., \& Zembylas, M. (2017). Mediating collective memories and official histories in conflict-affected societies: Pedagogical responses to "individual" narratives and competing collective memories. In H. Elmersjö, A. Clark, \& M. Vinterek (Eds.), International perspectives on teaching rival histories (pp. 133-153). London, United Kingdom: Palgrave Macmillan.

Bilali, R., \& Vollhardt, J. R. (2019). Victim and perpetrator groups' divergent perspectives on collective violence: Implications for intergroup relations. Political Psychology, 40, 75-108. https://doi.org/10.1111/pops.12570

Biton, Y., \& Salomon, G. (2006). Peace in the eyes of Israeli and Palestinian youths: Effects of collective narratives and peace education program. Journal of Peace Research, 43, 167-180. https://doi.org/10.1177/0022343306061888

Bobinac, U. (2015). Same soil, different roots: The use of ethno-specific narratives during the Homeland War in Croatia [Master's thesis, University of Washington, Seattle, WA, USA]. Retrieved from http://hdl.handle.net/1773/33524

Braga, L. L., Mello, M. F., \& Fiks, H. P. (2012). Transgenerational transmission of trauma and resilience: A qualitative study with Brazilian offspring of Holocaust survivors. BMC Psychiatry, 12, Article 134. https://doi.org/10.1186/1471-244X-12-134

Braun, V., \& Clarke, V. (2006). Using thematic analysis in psychology. Qualitative Research in Psychology, 3, 77-101. https://doi.org/10.1191/1478088706qp063oa

Cairns, E., \& Roe, M. D. (2003). Why memories in conflict. In E. Cairns \& M. D. Roe (Eds.), The role of memory in ethnic conflict (pp. 3-8). New York, NY, USA: Palgrave.

Cikara, M., \& Fiske, S. T. (2012). Stereotypes and Schadenfreude: Affective and physiological markers of pleasure at outgroup misfortunes. Social Psychological \& Personality Science, 3, 63-71. https://doi.org/10.1177/1948550611409245

Clark, J. N. (2012). The ICTY and reconciliation in Croatia: A case study of Vukovar. Journal of International Criminal Justice, 10, 397-422. https://doi.org/10.1093/jicj/mqs017

Cohen, J. (1992). A power primer. Psychological Bulletin, 112(1), 155-159. https://doi.org/10.1037/0033-2909.112.1.155

Čorkalo Biruški, D. (2012). Lessons learned from the Former Yugoslavia: The case of Croatia. In D. Landis \& R. Albert (Eds.), Handbook of ethnopolitical conflict (pp. 327-348). New York, NY, USA: Springer.

Čorkalo Biruški, D. (2016). Determinants of post-conflict trust: The role of ethnic identity, personal and collective victimization and intergroup emotions. In I. Alon \& D. Bar-Tal (Eds.), The role of trust in conflict situations: The Israeli-Palestinian case and beyond (pp. 59-80). New York, NY, USA: Springer.

Čorkalo Biruški, D., \& Ajduković, D. (2009). Od dekonstrukcije do rekonstrukcije traumatizirane zajednice: Primjer Vukovara [From deconstruction to reconstruction of a traumatised community: The example of Vukovar]. Revija za Socijalnu Politiku, 16, 1-24. https://doi.org/10.3935/rsp.v16i1.774

Čorkalo Biruški, D., \& Ajduković, D. (2012). Parallel worlds of divided community: Time does not make much difference. In O. Simić, Z. Volčič, \& C. R. Philpot (Eds.), Peace psychology in the Balkans: Dealing with a violent past while building peace (pp. 177-198). New York, NY, USA: Springer.

Čorkalo Biruški, D., \& Ajduković, D. (2016). Young adults' perspective of social reconstruction in three post-war communities in Croatia and Bosnia and Herzegovina. In M. Fischer \& O. Simic (Eds.), Transitional justice and reconciliation: Lessons from the Balkans (pp. 169-192). New York, NY, USA: Routledge.

Čorkalo Biruški, D., Ajduković, D., \& Löw Stanić, A. (2014). When the world collapses: Changed worldview and social reconstruction in a traumatized community. European fournal of Psychotraumatology, 5, Article 24098.

Čorkalo Biruški, D., \& Penić, S. (2014). Traumatised selves: Does war trauma facilitate ingroup bonding and outgroup distancing? In D. Spini, G. Elcheroth, \& D. Corkalo Biruski (Eds.), War, community, and social change: Collective experiences in the Former Yugoslavia (pp. 137-153). New York, NY, USA: Springer. 
Croatia: Law of 1996 on General Amnesty, 5 October 1996, available at: https://www.refworld.org/docid/3ae6b4de2c.html

Croatian Bureau of Statistics. (2009, 2011). Statistical information. Published and printed by the Central Bureau of Statistics of the Republic of Croatia, Zagreb.

Denzin, N. K., \& Lincoln, Y. S. (2005). The SAGE handbook of qualitative research. Thousand Oaks, CA, USA: SAGE.

Doosje, B., Branscombe, N. R., Spears, R., \& Manstead, A. S. R. (1998). Guilty by association: When one's group has a negative history. fournal of Personality and Social Psychology, 75, 872-886. https://doi.org/10.1037/0022-3514.75.4.872

Doosje, B., Ellemers, N., \& Spears, R. (1995). Perceived intragroup variability as a function of group status and identification. fournal of Experimental Social Psychology, 31, 410-436. https://doi.org/10.1006/jesp.1995.1018

Eastmond, M. (2010). Reconciliation, reconstruction, and everyday life in war-torn societies. Focaal-fournal of Global and Historical Anthropology, 57, 3-16.

Elliot, V., Cammer, A., Pickett, W., Marlenga, B., Lawson, J., Dosman, J., . . Trask, C. (2018). Towards a deeper understanding of parenting on farms: A qualitative study. PLoS One, 13, Article e0203842. https://doi.org/10.1371/journal.pone.0198796

Fiske, S. T., Cuddy, A. J. C., Glick, P., \& Xu, J. (2002). A model of (often mixed) stereotype content: Competence and warmth respectively follow from perceived status and competition. fournal of Personality and Social Psychology, 82, 878-902. https://doi.org/10.1037/0022-3514.82.6.878

Glick, P., \& Fiske, S. T. (2001). An ambivalent alliance: Hostile and benevolent sexism as complementary justifications for gender inequality. The American Psychologist, 56, 109-118. https://doi.org/10.1037/0003-066X.56.2.109

Halperin, E., Sharvit, K., \& Gross, J. J. (2011). Emotion and emotion regulation in intergroup conflict: An appraisal-based framework. In D. Bar-Tal (Ed.), Intergroup conflicts and their resolution: A social psychological perspective (pp. 83-103). New York, NY, USA: Psychology Press.

Hameiri, B., \& Nadler, A. (2017). Looking backward to move forward: Effects of acknowledgment of victimhood on readiness to compromise for peace in the protracted Israeli-Palestinian conflict. Personality and Social Psychology Bulletin, 43, 555-569. https://doi.org/10.1177/0146167216689064

Harris, L. T., \& Fiske, S. T. (2006). Dehumanizing the lowest of the low: Neuro-imaging responses to extreme outgroups. Psychological Science, 17, 847-853. https://doi.org/10.1111/j.1467-9280.2006.01793.x

Hayes, A. F. (2018). Introduction to mediation, moderation, and conditional process analysis: A regression-based approach (2nd ed.). New York, NY, USA: The Guilford Press.

Haukanes, H., \& Trnka, S. (2013). Memory, imagination and belonging across generations: Perspectives from postsocialist Europe and beyond. Focaal: Journal of Global and Historical Anthropology, 2013(66), 3-13. https://doi.org/10.3167/fcl.2013.660101

HINA. (2018, October 13). Jezive ispovijesti o mučenjima [Horrible confessions about torture]. Retrieved from https://www.jutarnji.hr/vijesti/hrvatska/jezive-ispovijesti-o-mucenjima-na-vukovarskom-skupu-potresna-svjedocanstva-u-tisinisu-se-slusali-iskazi-zrtava-pavle-vukasa-mladena-roguljica/7938349/

Hughes, J., Turner, R., Blaylock, D., \& Jost, D. (2020). Education in divided societies: Developing and researching shared education in the Republic of Macedonia, Bosnia and Herzegovina, and Croatia. Retrieved from https://gtr.ukri.org/projects?ref=ES\%2FP006655\%2F1

Iqbal, Y., \& Bilali, R. (2018). The impact of acknowledgment and denial of responsibility for harm on victim groups' perceptions of justice, power, and intergroup attitudes. European fournal of Social Psychology, 48, 397-411. https://doi.org/10.1002/ejsp.2338

Immigration and Refugee Board of Canada. (2006). Treatment of ethnic Serbs and available state protection (2003 - 2005)

[HRV100745.E]. Retrieved from http://www.ecoi.net/local_link/179291/281669_en.html

Jelić, M., Čorkalo Biruški, D., \& Ajduković, D. (2013). Predictors of collective guilt after the violent conflict. Collegium Antropologicum, 37, 1-10.

Kardov, K., Lalić, D., \& Teršelić, V. (2010). Suočavanje s prošlošću u Hrvatskoj: Stavovi i mišljenja aktera i javnosti u poraću [Dealing with the past in Croatia: Attitudes and opinions of actors and the public after the war]. Zagreb, Croatia: Documenta.

Kratochwil, F. (2006). History, action and identity: Revisiting the 'second' great debate and assessing its importance for social theory. European fournal of International Relations, 12, 5-29. https://doi.org/10.1177/1354066106061323

Mackie, D. M., Smith, E. R., \& Ray, D. G. (2008). Intergroup emotions and intergroup relations. Social and Personality Psychology Compass, 2, 1866-1880. https://doi.org/10.1111/j.1751-9004.2008.00130.x

Manojlović, N. (2018, July 9). Koliko Srba radi u javnom sektoru Vukovarsko-sremske županije? [How many Serbs work in the public sector in Vukovarsko-srijemska County?] Srbi.hr. Retrieved from

https://srbi.hr/koliko-srba-radi-u-javnom-sektoru-vukovarsko-sremske-zupanije/ 
McDowell, S., \& Braniff, M. (2014). Commemoration as conflict: Space, memory and identity in peace processes. Basingstoke, United Kingdom: Palgrave Macmillan UK.

McGrattan, C., \& Hopkins, S. (2017). Memory in post-conflict societies: From contention to integration? Ethnopolitics, 16, 488-499. https://doi.org/10.1080/17449057.2016.1218644

McQuaid, S. D. (2015). Commemoration as conflict: Space, memory and identity in peace processes. Irish Political Studies, 31, 597-599. https://doi.org/10.1080/07907184.2015.1060001

Mikić, L. J., \& Božić, S. (2014). Neostvarena prava i promašene politike: Zastupljenost nacionalnih manjina u državnoj upravi, pravosuđu i policiji [Unfulfilled rights and failed policies: Representation of national minorities in public administration, judiciary and police]. SNV Bulletin, 1. Zagreb, Croatia: SNV.

Močnik, N. (2019). How (long) to mourn the pedagogical implications of imposed remembrance practices: Two cases from BosniaHerzegovina. Fournal of Peace Education and Social fustice, 13, 70-92.

Nadler, A. (2002). Post-resolution processes: Instrumental and socio-emotional routes to reconciliation. In G. Salomon \& B. Nevo (Eds.), Peace education: The concept, principles, and practices around the world (pp. 127-141). Mahwah, NJ, USA: Lawrence Erlbaum Associates.

Nadler, A., \& Liviatan, I. (2004). Intergroup reconciliation processes in Israel: Theoretical analysis and empirical findings. In N. R. Branscombe \& B. Doosje (Eds.), Collective guilt international perspectives (pp. 261-235). Cambridge, United Kingdom: Cambridge University Press.

Noor, M., Brown, R., Gonzalez, R., Manzi, J., \& Lewis, C. A. (2008). On positive psychological outcomes: What helps groups with a history of conflict to forgive and reconcile with each other? Personality and Social Psychology Bulletin, 34, 819-832. https://doi.org/10.1177/0146167208315555

Noor, M., Brown, R. J., \& Prentice, G. (2008). Precursors and mediators of intergroup reconciliation in Northern Ireland: A new model. British fournal of Social Psychology, 47, 481-495. https://doi.org/10.1348/014466607X238751

Noor, M., Shnabel, N., Halabi, S., \& Nadler, A. (2012). When suffering begets suffering. Personality and Social Psychology Review, 16, 351-374. https://doi.org/10.1177/1088868312440048

Orešić, B. (2018, October 11). Koga je abolirao Tuđman [Who was granted abolition by Tuđman]. Globus. Retrieved from https:/www.jutarnji.hr/globus/Globus-politika/koga-je-abolirao-tudman-o-zapaljivom-pitanju-za-globus-govore-svjedocivremena-kako-je-zakonom-o-opcem-oprostu-placena-cijena-mirne-reintegracije/7929043/

Patković, N. (2018, October 27). Žrtve rata o kojima se ne govori [Victims of war that are not talked about]. Futarnji list. Retrieved from

https://www.vecernji.hr/vijesti/je-li-moguca-pomirba-u-vukovaru-analiziramo-koji-su-preduvjeti-za-suzivot-hrvata-isrba-1283754

Penić, G. (2018, October 14). Kako je Plenković dvjema riječima rastjerao HZD-ovce iz Vukovara [How Plenković with two words dispelled HDZ members from Vukovar]. Jutarnji list. Retrived from https://www.jutarnji.hr/vijesti/hrvatska/kako-je-plenkovic-dvjema-rijecima-rastjerao-hdz-ovce-iz-vukovara-ovaj-skup-je-jasnopokazao-kakva-je-buducnost-svih-buducih-slicnih-dogadanja-naroda/7938796/

Phalet, K., \& Poppe, E. (1997). Competence and morality dimensions of national and ethnic stereotypes: A study in six EasternEuropean countries. European fournal of Social Psychology, 27, 703-723. https://doi.org/10.1002/(SICI)1099-0992(199711/12)27:6<703::AID-EJSP841>3.0.CO;2-K

Popov, A., \& Deak, D. (2015). Making sense of the 'difficult' past: Transmission of political heritage and memory-work among young people across Europe. The Sociological Review, 63, 36-52. https://doi.org/10.1111/1467-954X.12261

Poppe, E., \& Linssen, H. (1999). In-group favoritism and the reflection of realistic dimensions of difference between national states in Central and Eastern European nationality stereotypes. British fournal of Social Psychology, 38, 85-102. https://doi.org/10.1348/014466699164059

Psaltis, C., Carretero, M., \& Čehajić-Clancy, S. (2017). Conflict transformation and history teaching: Social psychological theory and its contributions. In C. Psaltis, M. Carretero, \& S. Čehajić-Clancy (Eds.), History education and conflict transformation (pp. 1-34). New York, NY, USA: Palgrave Macmillan.

Psaltis, C., Franc, R., Smeekes, A., Ioannou, M., \& Žeželj, I. (2017). Social representations of the past in post-conflict societies: Adherence to official historical narratives and distrust through heightened threats. In C. Psaltis, M. Carretero, \& S. Čehajić-Clancy (Eds.), History education and conflict transformation (pp. 97-122). New York, NY, USA: Palgrave Macmillan. 
Raknić, D. (2018, November 17). Pupovac odao počast žrtvama u Vukovaru: Pratila ga je policija, dio branitelja i građana okrenuo mu je leđa [Pupovac honors victims in Vukovar: He was followed by the police, some defenders and citizens turned their back on him]. Jutarnji list. Retrieved from

https://www.jutarnji.hr/vijesti/hrvatska/pupovac-odao-pocast-zrtvama-u-vukovaru-pratila-ga-je-policija-dio-branitelja-i-gradanaokrenuo-mu-je-leda-8068463

Rašović, R., \& Boban Valečić, I. (2018, November 20). Je li moguća pomirba u Vukovaru? [Is reconciliation possible in Vukovar?] Večernji list. Retrieved from https://www.vecernji.hr/vijesti/je-li-moguca-pomirba-u-vukovaru-analiziramo-koji-su-preduvjeti-za-suzivot-hrvata-isrba-1283754

Reidy, C. M., Taylor, L. K., Merrilees, C. E., Ajduković, D., Čorkalo Biruški, D., \& Cummings, E. M. (2015). The political socialization of youth in a post-conflict community. International fournal of Intercultural Relations, 45, 11-23. https://doi.org/10.1016/j.ijintrel.2014.12.005

Ruck, M. D., Mistry, R. S., \& Flanagan, C. A. (2019). Children's and adolescents' understanding and experiences of economic inequality: An introduction to the special section. Developmental Psychology, 55, 449-456. https://doi.org/10.1037/dev0000694

Sabljak Gojani, S. (2011, April 23). Sramota - spomenici koji veličaju krvnika, a omalovažavaju žrtvu [Shame - Tumbstones that glorify executioners, and derogate the victim]. Večernji list. Retrieved from https://blog.vecernji.hr/sandra-sabljak/sramota-spomenici-koji-velicaju-krvnika-a-omalovazavaju-zrtvu-3436

Sekulić, D., Massey, G., \& Hodson, R. (2006). Ethnic intolerance and ethnic conflict in the dissolution of Yugoslavia. Ethnic and Racial Studies, 29, 797-827. https://doi.org/10.1080/01419870600814247

Stockholm International Peace Research Institute. (1995-1996) Annual Report. Stockholm, Sweden: Author.

Smeekes, A., McKeown, S., \& Psaltis, C. (2017). Endorsing narratives under threat: Maintaining perceived collective continuity through the protective power of ingroup narratives in Northern Ireland and Cyprus. Fournal of Social and Political Psychology, 5 , 282-300. https://doi.org/10.5964/jspp.v5i2.682

Smith, K. (2019). A monument for our time? Conmmemorating victims of repression in Putin's Russia. Europe-Asia Studies, 71, 1314-1344. https://doi.org/10.1080/09668136.2019.1648765

Subotić, J. (2013). Stories states tell: Identity, narrative, and human rights in the Balkans. Slavic Review, 72, 306-326. https://doi.org/10.5612/slavicreview.72.2.0306

Švaříčková Slabáková, R. (2019). Moral heroes or suffering persons? Ancestors in family intergenerational stories and the intersection of family and national memories. Journal of Family History, 44, 431-448. https://doi.org/10.1177/0363199019863463

Tam, T., Hewstone, M., Cairns, E., Tausch, N., Maio, G., \& Kenworthy, J. (2007). The impact of intergroup emotions on forgiveness in Northern Ireland. Group Processes \& Intergroup Relations, 10, 119-136. https://doi.org/10.1177/1368430207071345

van de Ven, C. (2015, November 20). Vukovar: Still devided by war. Al fazeera. Retrieved from https://www.aljazeera.com/indepth/features/2015/11/vukovar-divided-war-croatia-serbia-massacre-151120090853383.html

Vezzali, L., Capozza, D., Stathi, S., \& Giovannini, D. (2012). Increasing outgroup trust, reducing infrahumanization, and enhancing future contact intentions via imagined intergroup contact. fournal of Experimental Social Psychology, 48, 437-440. https://doi.org/10.1016/j.jesp.2011.09.008

Vollhardt, J. R. (2012). Collective victimization. In L. Tropp (Ed.), The Oxford handbook of intergroup conflict (pp. 136-15). Oxford, United Kingdom: Oxford University Press.

Vollhardt, J. R. (2015). Inclusive victim consciousness in advocacy, social movements, and intergroup relations: Promises and pitfalls. Social Issues and Policy Review, 9, 89-120. https://doi.org/10.1111/sipr.12011

Vollhardt, J. R., Mazur, L. B., \& Lemahieu, M. (2014). Acknowledgment after mass violence: Effects on psychological well-being and intergroup relations. Group Processes \& Intergroup Relations, 17, 306-323. https://doi.org/10.1177/1368430213517270

Vollhardt, J. R., \& Twali, M. S. (2016). Emotion-based reconciliation requires attention to power differences, critical consciousness, and structural change. Psychological Inquiry, 27, 136-143. https://doi.org/10.1080/1047840X.2016.1160762

Weinstein, H. M., Freedman, S. W., \& Hughson, H. (2007). School voices: Challenges facing education systems after identity-based conflicts. Education, Citizenship and Social fustice, 2, 41-71. https://doi.org/10.1177/1746197907072128

Weiss, D. S., \& Marmar, C. R. (1996). The Impact of Event Scale - Revised. In J. Wilson \& T. M. Keane (Eds.), Assessing psychological trauma and PTSD (pp. 399-411). New York, NY, USA: Guilford. 
Wolnik, K., Busse, B., Tholen, J., Yndigegn, C., Levinsen, K., Saari, K., \& Puuronen, V. (2017). The long shadows of the difficult past?

How young people in Denmark, Finland and Germany remember WWII. fournal of Youth Studies, 20, 162-179.

https://doi.org/10.1080/13676261.2016.1206866

Žanić, M., Kufrin, K., \& Živić, D. (2016). Culture and remembrance of war: The battle of Vukovar and its social repercussions.

Migracijske i Etnicke Teme, 32, 245-270.

\section{Appendices}

\section{Appendix A: Indicators of All Measures Used in Study 1}

\section{Ethnic identification}

- I see myself as a Croat/Serb.

- I am glad to be Croat/Serb

- I feel strong attachment to other Croats/Serbs.

- I identify with Croats/Serbs.

\section{Exposure to traumatic events}

Čorkalo Biruški and Ajduković, 2009

List of 12 stressful events:

- Poor diet

- Changing the social environment

- Low monthly income, material deprivation

- Exposure to weather disasters for a long time

- Sharing a living space with previously unknown people

- Loss or heavy damage to movable property

- Loss of very important personal belongings

- Loss of employment

- Loss of business opportunities

- Exposure to hunger for a long time

- Separation from spouse (due to exile)

- Loss or serious damage to immovable property

List of 14 traumatic events:

- Separation from adult children (due to exile)

- Departing family members to war

- Interrogation by the enemy

- Forced leave of residence

- Wounding of a close family member

- Direct exposure to war actions (bombings, attacks on the city)

- Separation from minor children (due to exile)

- Personal detention

- Being wounded

- Wittnessing other people's death

- Wittnessing violence over other people

- witnessing a rape

- death of a friend or family member

- being a rape victim

\section{Impact of events scale}

IES-R; Weiss, \& Marmar, 1996

Below is a list of the difficulties people sometimes have after stressful life events. Please read each sentence and estimate how much each of the above difficulties has bothered you over the past 7 days because of what happened to you during the war.

Perceived ingroup accountability

My group was a victim in the war and therefore we cannot be responsible for the atrocities that were committed. 


\section{Measure of competitive victimhood}

Which group (Croats or Serbs) was the greater victim in the war?

- $1=$ Serbs were greater victims

- $2=$ Both groups were equal victims

- $3=$ Croats were greater victims

\section{Perceived post-war victimization}

Have you or close members of your family experienced unequal treatment after the war due to your ethnicity in each of the following areas:

- schooling

- healthcare

- employment

- housing

- judiciary

- police procedures

\section{Outgroup stereotypes}

- Competence dimension: lazy-diligent, courageous-coward, stupid-smart, uncultivated-decent, dirty-clean

- Warmth dimension: insolent-kind, selfish-unselfish, hospitable-inhospitable, do not like other nations - like other nations

\section{Positive outgroup affects}

Indicate to what extent do you, as a member of your ethnic group, feel each emotion toward the Serbs/Croats

- friendship

- respect

- closeness

- conciliatory

\section{Intergroup rapprochement}

- I believe that working on common goals is the best way to restore trust between Croats and Serbs.

- I believe in the principle "an eye for an eye, and a tooth for a tooth".

- I think that the trust between Croats and Serbs has been lost forever.

- I think that it is impossible to overcome injuries that were inflicted in the last war between Croats and Serbs.

- I can be close with some members of the other group, but generally I do not trust them.

- I do not trust people from the other ethnic group.

- One should always be cautious in relations with the other group.

Perceived preconditions for reconciliation

What are the necessary conditions for reconciliation between Croats and Serbs?

- 1 = reconciliation should not take place,

- 2 = reconciliation is possible if all the wrongdoings committed by the outgroup are punished,

- $3=$ intergroup relations are going to normalize by themselves in time,

- 4 = each side needs to point to culprits for the war,

- 5 = we $($ Croats/Serbs) should make the first move towards reconciliation. 


\section{Appendix B: The Content Categories of War Narrative and Reconciliation, and Corroborating Primary Data}

\section{Content category of war narrative}

1. Showing interest on the issue

2. Major transmitter of the narrative (Who do they talk to about the issues?)

\section{Corroborating primary data}

- Watching documentaries

- Talk to family members what happened, how the war started, how the parents felt.

- Asking questions about father's experience in POW camp.

- Declaring openly no interest whatsoever.

- Family stories about losses, bombing, flight, fights with no much details. Clear emotional responses (fear, sorrow, terror) about what happened are verbalized.

- Commemorative practices in school: Croat children are aware that Serb peers do not observe these occasions.

- Some talk about not learning about the war in schools, the role of school emphasized only in relation to commemoration.

- Some silence in families with losses - it is too hard to talk about it.

- Media (aggressive) coverage (especially TV) of war issues. Adults in some families do correct what children hear on TV.

- No exchange with peers.

\section{Content category of reconciliation}

1. Possibilities for reconciliation (is it possible at all?)

2. Actors of reconciliation (Who could reconcile sooner those younger or older?)

3. Ways of reconciliation (How it would look like if Croats and Serbs reconcile?)

\section{Corroborating primary data}

- Clear expression on positive or negative responses.

- Expression of doubts and related explanation (e. g. the wounds are too deep; older pass on to the youngest their negative past experiences and hatred)

- Older people could reconcile sooner because younger people do not understand what happened in the war.

- Younger people could reconcile sooner because what happened in the war is a great burden for the older.

- There is some hope in younger generation because they do not know what happened in the war and in time they will not care about those issue at all.

- Only the next generation could do it.

- Political parties, "both sides" should work on reconciliation.

- No idea about reconciliation shared (do not know)

- If Croats and Serbs live in separated countries.

- They can live in the same state again.

- There will be no fights anymore.

- It will be less tense.

- Everybody will go out at the same places.

- No problems with employment.

- Even if they reconcile, there will be again fights and then the war will start again.

- There is no much of it that Croat could do, because they do not want to (they, i. e. Serbs, attacked us).

- Time (for healing and for distancing from the past) is an important factor.

- Croats should stop rubbing Serbian noses in the war.

- Some people cannot forget ever, but some can and will

- Reconciliation is possible if the past is forgotten.

- Equality is a prerequisite for reconciliation.

- Serbs should stop insisting on their "special" rights (i. e. schools, Cyrillic script in public etc).

- Both sides should talk to each other about the issue. 